\title{
Cribrilinid bryozoans from Pleistocene Mediterranean deep-waters, with the description of new species
}

\author{
Antonietta Rosso, ${ }^{1,2}$ Emanuela Di Martino, ${ }^{3 *}$ (1) and Andrew N. Ostrovsky ${ }^{4,5}$ (i) \\ ${ }^{1}$ Dipartimento di Scienze Biologiche, Geologiche e Ambientali, University of Catania, Corso Italia 57, 95129, Catania, \\ Italy <rosso@unict.it> \\ ${ }^{2}$ CoNISMa (Consorzio Interuniversitario per le Scienze del Mare), Piazzale Flaminio 9, 00196, Roma, Italy \\ ${ }^{3}$ Natural History Museum, University of Oslo, Blindern, P.O. Box 1172, Oslo 0318, Norway <e.d.martino@nhm.uio.no> \\ ${ }^{4}$ Department of Invertebrate Zoology, Faculty of Biology, Saint Petersburg State University, Universitetskaja nab. 7/9, 199034, Saint \\ Petersburg, Russia <a.ostrovsky@spbu.ru> \\ ${ }^{5}$ Department of Palaeontology, Faculty of Earth Sciences, Geography and Astronomy, University of Vienna, Althanstr. 14, 1090, Vienna, \\ Austria <andrei.ostrovsky@univie.ac.at>
}

\begin{abstract}
Cribrilinid bryozoans originating from Pleistocene deep-water sediments from two localities near Messina (Sicily, Italy)_Capo Milazzo (Gelasian) and Scoppo (Calabrian)_were examined. Five cribrilinid species were found, three in each locality and time interval, with only one species shared. Three species, Cribrilaria profunda n. sp., Glabrilaria transversocarinata n. sp., and Figularia spectabilis n. sp., are new to science. Of the two remaining species, Figularia figularis was already known from local fossil associations, whereas Glabrilaria pedunculata, a present-day Mediterranean species, is recorded for the first time as a fossil. New combinations are suggested for two species previously assigned to Puellina, Cribrilaria saldanhai (Harmelin, 2001) n. comb. and Cribrilaria mikelae (Harmelin, 2006) n. comb. The diagnosis of the genus Figularia was amended to include an erect growth morphology in addition to the encrusting form, and the occurrence of ooecia formed by the distal kenozooid. Following a literature revision of all species currently assigned to Figularia, the new combinations Vitrimurella capitifera (Canu and Bassler, 1929) n. comb. and Hayamiellina quaylei (Powell, 1967a) n. comb. are suggested, and problematic species are listed and briefly discussed.
\end{abstract}

UUID: http://zoobank.org/b7b36152-bf7b-4e00-b6ec-2614b2a58f1b

\section{Introduction}

Cribrilinidae Hincks, 1879 is an extremely large family of cheilostome bryozoans including 127 genera and more than 700 living and fossil species to date, accounting for $\sim 3 \%$ of total bryozoan diversity (Bock, 2020). First appearing ca. $100 \mathrm{Ma}$, in the Cenomanian, Cribrilinidae underwent a peak of diversification during the Santonian, greatly contributing to the radiation of cheilostomes in the Late Cretaceous (Cheetham, 1971; Jablonski et al., 1997 and references therein). This family is one of the most species-rich in the present-day Mediterranean (Rosso and Di Martino, 2016), as well as in other regions of the world (e.g., Gordon et al., 2019). Cribrilinids exhibit a typical and distinctive costate frontal shield, but also high morphological variability, including different types of heteromorphs (avicularia, kenozooids, articulated and non-articulated spines, etc.) and ovicell structures. A future subdivision of Cribrilinidae into several families or subfamilies is very likely. A more accurate definition of certain genera will, however, require a thorough re-examination of the original material, particularly

*Corresponding author of the numerous Cretaceous representatives (e.g., Taylor and McKinney, 2006; Rosso et al., 2018), as well as phylogenetic analyses. Genus and species identification are often based on subtle morphological characters, such as those associated with the zooidal orifice and the suboral bar (e.g., Harmelin, 1970, 1978, 2001, 2006; Bishop and Househam, 1987), which require scanning electron microscopy (SEM), still lacking in the descriptions of numerous taxa. In fossil material, identification of taxa is also jeopardized by taphonomic filters, with abrasion, corrosion, partial dissolution and recrystallization obliterating fine diagnostic characters. This is particularly true for species introduced in old publications, normally including only brief descriptions and often lacking proper illustrations. Descriptions and revisions of fossil cribrilinids based on detailed illustrations are scarce in the modern literature, especially for specific stratigraphic intervals (Berning, 2006; Taylor and McKinney, 2006; Di Martino and Rosso, 2015). In this context, this paper aims to: (1) document cribrilinid associations from Pleistocene deep-water habitats of southern Italy; (2) illustrate fossil representatives of some established species; (3) describe three new species; (4) amend the diagnosis of the genus Figularia Jullien, 1886, and provide a comparative morphological analysis of species currently assigned to this genus; and (5) propose new 
combinations for two species of Puellina and two species of Figularia.

\section{Geological setting}

North-eastern Sicily is part of the north Sicily Chain, which, in this sector, includes the Kabilo-Calabride crystalline basement (Paleozoic rocks of different metamorphic grade) and its sedimentary cover (i.e., discontinuous upper Miocene sediments unconformably covered by Plio-Pleistocene deposits; Barrier, 1987). The Plio-Pleistocene succession starts with lower Pliocene deep-water whitish foraminiferal marls, marly limestones, and coarser sediments including breccias, overlaid with middle Pliocene to middle Pleistocene sediments, usually in thin discontinuous, often laterally heteropic bodies. Those bodies can be grouped in: (1) a middle Pliocene-middle Pleistocene "Bathyal Facies Association" (PP), and (2) a middle Pleistocene "Circalittoral-Infralittoral Facies Association" (mP) (Barrier, 1987; Barrier et al., 1987a; Vertino, 2003). PP includes carbonatedominated and siliciclastic-dominated facies. The former facies mainly consist of coral-rich rudstones, with the frame-building deep-water scleractinians Madrepora oculata Linnaeus, 1758, Desmophyllum pertusum (Linnaeus, 1758), and D. dianthus (Esper, 1794), interfingered with calcarenites and carbonate sands containing scattered isidid octocorals, and locally truncated by erosional surfaces and overlaid with debris-flow deposits. The siliciclastic-dominated facies are mainly characterized by marly and silty clays, sometimes embedding coral rudstone boulders that are often encrusted by corals, bivalves, serpulids, and bryozoans (Barrier, 1986, 1987; Barrier et al., 1996). Facies mP includes the "upper gravels and sands" with fossils of infralittoral-upper circalittoral origin and, locally, large blocks encrusted by circalittoral organisms, and Gilbert-type delta deposits regionally known as the "Messina Formation." The succession is erosionally capped by Upper Pleistocene fluvio-marine terraces.

At Capo Milazzo, the so-called "yellow calcareous marl" crops out along the south-western and the north-eastern coast. The sandy-silty sediments unconformably lie on erosive surfaces of the pre-Messinian basement (Paleozoic metamorphites to upper Miocene shallow-water deposits), constituting discontinuous sedimentary bodies filling small depressions (Fois, 1990). Sediment deposition, previously dated as late Pliocene, occurred during the MP15 and MP16 zones, largely overlapping with the Gelasian Stage of Rio et al. (1994), and now considered as the basal part of the Pleistocene (Gibbard et al., 2010; Violanti, 2012). Deposition in epibathyal environments is indicated by both macrofaunal associations, including brachiopods, corals, serpulids, and, occasionally, mollusks (e.g., Gaetani and Saccà, 1984; Langer, 1989), as well as microfaunas, including foraminiferans and ostracodes (e.g., Violanti, 1988; Sciuto, 2014a, b). Bryozoans are common, but hardly detectable in the field owing to the small size of their colonies and/or colony fragments. Bryozoan assemblages are very diverse, including up to 60 species, some exclusively found in these deposits (Rosso, 2002a, b, 2005; Rosso and Braga, 2013; Rosso and Di Martino, 2015; Rosso and Sciuto, 2019).

Scoppo is located immediately west of the city of Messina, in the Messina Strait area, where Pleistocene bathyal sediments discontinuously occur (Barrier, 1984; Barrier et al., 1987a;

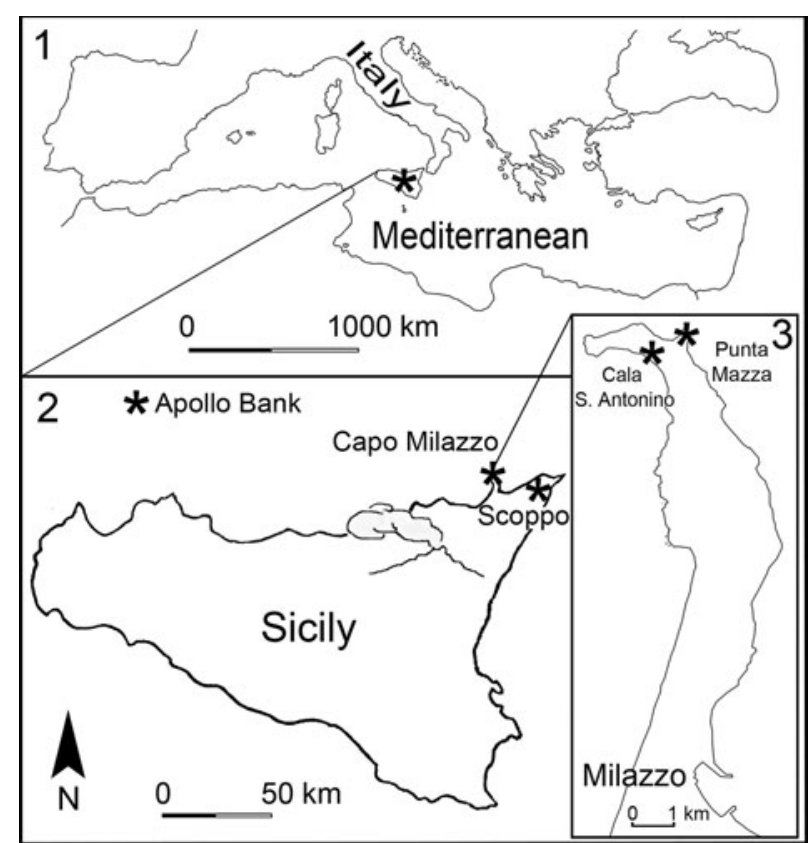

Figure 1. Location of (1) Sicily in the Mediterranean Sea and (2) the study area in northeastern Sicily with sampling localities (Capo Milazzo, Scoppo, and the Apollo Bank, see asterisks); (3) shows Cala Sant'Antonino and Punta Mazza sections at Capo Milazzo. Modified from Rosso and Sciuto (2019).

Vertino, 2003). At Scoppo, these sediments unconformably lie on Messinian brecciated evaporitic limestone. They consist of basal rudstones rich in fragments of cold-water corals (i.e., $M$. oculata, D. pertusum, and $D$. dianthus) that are overlain by poorly cemented white marls with sparse corals and plates of the cirriped Scillaelepas Seguenza, 1876. These macrofossils, and ostracodes, point to deposition in bathyal environments (Vertino et al., 2013; Sciuto, 2016) in the MNN19b-19c biozones (A. Baldanza, personal communication, 2015), corresponding to the early Calabrian (=Santernian).

\section{Materials and methods}

Studied material originates from deep-water sediments cropping out in two different localities near Messina in north-eastern Sicily: Capo Milazzo Peninsula (two outcrops: Cala Sant'Antonino and Punta Mazza) and Scoppo (Fig. 1; see Geological setting for details). Additional material used for comparison derives from a present-day submarine sample collected at the Apollo Bank off Ustica Island in the Tyrrhenian Sea (Fig. 1).

At Capo Milazzo, cribrilinid bryozoans were found in "sample 1 (1999)" collected near the top of the layers exposed at Cala Sant'Antonino West; "sample 17 (2000)" and "sample 2015" collected in the central part of Cala Sant'Antonino outcrop; and "sample 4" and "sample 5" collected in biogenic layers near the base of Punta Mazza section, corresponding to "sample 12" and "sample 11" of Sciuto (2014b), respectively. Further information on these samples can be found in Sciuto (2014b) and Rosso and Sciuto (2019). At Scoppo, cribrilinids were found in a test sample associated with a Scillaelepas-rich layer, and in the sample "Scoppo 24 top" coming from uncemented marly sediment. 
At the Apollo Bank, coarse sediments associated with the kelp Laminaria rodriguezii Bornet, 1888 were collected at about $60 \mathrm{~m}$ depth. Living and dead bryozoan associations were characterized by high species richness, but delivered only one colony (now fragmented) of Figularia figularis (Johnston, 1847) (Di Geronimo et al., 1990).

Sediment was routinely treated (washed, sieved, and dried) at the Paleoecological Laboratory of the University of Catania. All bryozoans were picked from residues larger than $0.5 \mathrm{~mm}$. After preliminary identification under a stereomicroscope, selected uncoated specimens were mounted for scanning electron microscopy (SEM) using a TESCAN VEGA 2 LMU in backscattered-electron/low-vacuum mode at the Microscopical Laboratory of the University of Catania. For the attribution of the specimens to the genera Cribrilaria Canu and Bassler, 1929 and Glabrilaria Bishop and Househam, 1987, we followed the diagnoses in Rosso et al. (2018) summarized herein: Cribrilaria has totally calcified non-pseudoporous ooecia produced by the distal autozooid or kenozooid, interzooidal avicularia of variable size and shape, usually five (4-8) oral spines, and relatively large uncalcified windows of pore-chambers; Glabrilaria has non-pseudoporous ooecia that are exclusively produced by the distal kenozooid, erect or semi-erect avicularia, 6-7 (rarely five) oral spines, small to moderately sized uncalcified windows of pore-chambers. Measurements were obtained from SEM images using the image processing program ImageJ (Schneider et al., 2012). Measurements were tabulated and provided in micrometers. The complete range is given first, followed by the mean value plus/minus standard deviation and the number of measurements taken. In specimens of Glabrilaria, zooidal boundaries were obliterated by recrystallisation with bands of crystals filling the interzooidal grooves. To estimate zooidal size, length was measured from the distal end of the orifice to the mid-point of the crystal band located proximally, while width was measured from mid-point to mid-point of the crystal bands located laterally.

Repositories and institutional abbreviations.-All specimens described and illustrated in this work are part of the Rosso Collection deposited at the Museum of Paleontology of the University of Catania (PMC) under the catalogue numbers reported in the "Systematic paleontology" section. Other abbreviations: MNHN, Muséum national d'Histoire naturelle, Paris; NHMUK, Natural History Museum, London; NMNH, National Museum of Natural History, Smithsonian Institution, Washington DC.

\section{Systematic paleontology}

Phylum Bryozoa Ehrenberg, 1831

Order Cheilostomatida Busk, 1852

Suborder Flustrina Smitt, 1868

Superfamily Cribrilinoidea Hincks, 1879

Family Cribrilinidae Hincks, 1879

Genus Cribrilaria Canu and Bassler, 1929

Type species._Eschara radiata Moll, 1803, by original designation.

\section{Cribrilaria profunda new species}

Figures 2, 3; Table 1

1988 Puellina (Cribrilaria) scripta; Harmelin and Aristegui, p. 526, figs. 18-19, 24.

1993 Puellina scripta; Harmelin and d'Hondt, fig. 5.

Holotype.-PMC. B27.10.10.2019a. Capo Milazzo Peninsula: Cala Sant'Antonino center, sample 2015: one small fragment including ovicellate zooids and interzooidal avicularia.

Paratypes.-PMC. B27.10.10.2019b. Additional specimens from Capo Milazzo Peninsula: Cala Sant'Antonino West, sample 1 (1999: surface): one specimen; Cala Sant'Antonino center, sample 17 (2000): three specimens; sample 2015: 12 specimens in addition to the holotype. PMC. B27.10.10.2019c. Scoppo: sample 24 top: two specimens.

Diagnosis.-Colonies encrusting, multiserial. Autozooids nearly flat, oval to irregularly polygonal. Basal pore-chambers present. Gymnocyst visible along the zooidal margins. Frontal shield consisting of 14-25 costae with 4-11 intercostal pores/ lacunae. Suboral bar formed by the first pair of widest costae with blunt median prominence and proximal pore. Orifice transversely D-shaped with five (occasionally 6-7) oral spines, four in ovicellate zooids. Interzooidal avicularia with elongate, triangular or parallel-sided, raised rostrum, crossbar lacking. Ovicell hyperstomial, presumably cleithral. Ooecium formed by distal autozooid, with a longitudinal median carina. Kenozooids rare.

Occurrence.-Cribrilaria profunda $\mathrm{n}$. sp. is presently known from the early Pleistocene deep-water deposits of southern Italy (Gelasian of Capo Milazzo Peninsula and early Calabrian of Scoppo, Messina), in the Recent Ibero-Moroccan Gulf (223-990 $\mathrm{m}$ depth), the Gibraltar Strait $(580 \mathrm{~m}$ depth) (Harmelin and Aristegui, 1988), and in the Alboran Sea (205 m) (Harmelin and d'Hondt, 1992, 1993).

Description.-Colonies encrusting, multiserial, unilaminar, the largest observed fragment including a dozen zooids. Zooids large and nearly flat, slightly longer than wide $(\mathrm{L} / \mathrm{W}=1.15$ : Scoppo; 1.29: Milazzo), oval to rhomboidal or rarely irregularly polygonal in shape, wider in their proximal half; zooidal boundaries marked by shallow grooves (Figs. 2.1, 2.4, 2.7, 3.1, 3.6). Gymnocyst exposed all along the zooidal margins, usually wider laterally to the orifice and at triple zooid junctions (Figs. 2.1, 3.1, 3.2). Interzooidal communication through basal pore-chambers with windows $(\sim 70 \times 20 \mu \mathrm{m})$, visible only in some zooids at colony periphery (Fig. 3.5). Frontal shield flat (Figs. 2.1, 2.7-2.9, 3.1, 3.2 ), consisting of 14-25 wedge-shaped costae (including suboral), narrowing and tapering towards the center of the zooid (maximum basal width 32-65 $\mu \mathrm{m}$ ), converging toward a median point or along a median longitudinal, transverse, or trifurcate midline. Costae connected by several intercostal 

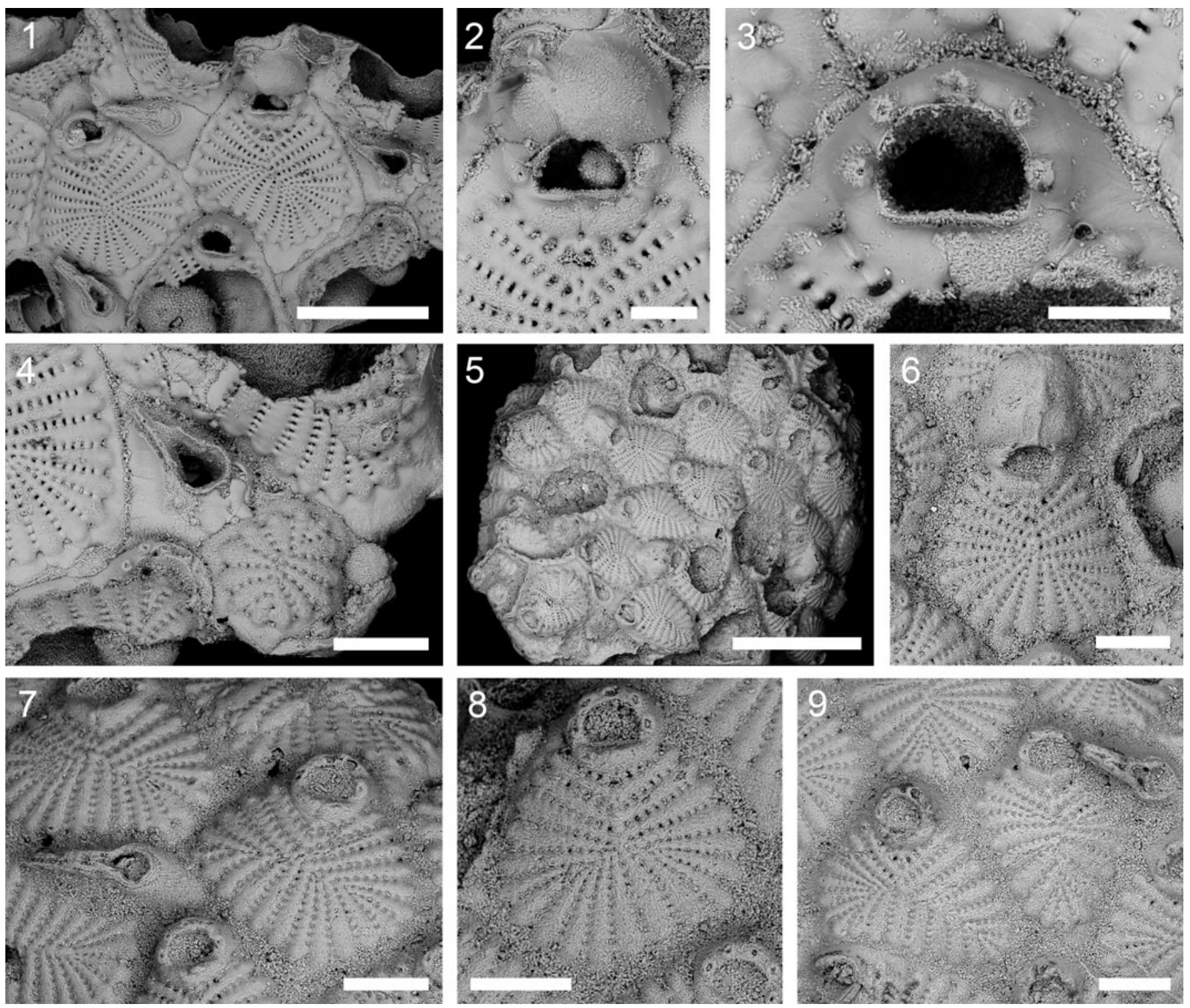

Figure 2. Cribrilaria profunda n. sp., Capo Milazzo, Gelasian. (1-4): PMC. B27.10.10.2019a, holotype with slightly recrystallized zooids, Cala Sant'Antonino center, sample 2015: (1) group of autozooids, some ovicellate, and interzooidal avicularia (ooecium shows no median carina); (2) distal part of an ovicellate zooid with four spine bases situated laterally to the orifice, the suboral bar, and intercostal lacunae; $(\mathbf{3})$ close-up of autozooidal orifice with five spine bases; (4) close-up of an avicularium and a kenozooid. (5-9) PMC. B27.10.10.2019b, same details as the holotype; one of the largest paratype specimens: (5) general view (note different zooidal shapes); (6) ovicellate zooid tilted to show the median carina of the ooecium; (7) autozooids and an avicularium; (8) an autozooid with recrystallized hidden margins; (9) autozooids of different shapes. Scale bars: (1) $500 \mu \mathrm{m} ;(\mathbf{2}, \mathbf{3}) 100 \mu \mathrm{m} ;(\mathbf{4 ,}, \mathbf{6 - 9}) 200 \mu \mathrm{m} ;(\mathbf{5}) 1 \mathrm{~mm}$.

bridges leaving 4-11, regularly spaced, subrectangular lacunae, $8-16 \mu \mathrm{m}$ long; peripheral pores the largest. Intercostal pores reduced to 4-5 proximally to the first suboral pair of costae (Fig. 2.2). These are shorter and larger than the other pairs, and merge along the zooidal midline leaving a suture with a median pore, and often forming a more or less elevated prominence distally, adjacent to the pore (Figs. 2.2, 3.3, 3.4). Orifice transversely D-shaped, outlined by a raised rim. Orifice bearing five (occasionally up to 7) equally spaced, articulated oral spines (Figs. 2.3, 3.3, 3.4), four persisting in ovicellate zooids (Fig. 2.2). Interzooidal avicularia common, directed laterally or rarely distolaterally, with a variably shaped (often triangular) cystid and an elongate triangular to almost parallel-sided rostrum, raised above or positioned between the costate shield of adjacent autozooids, no crossbar (Figs. 2.1, 2.4, 2.7, 2.9, 3.5, 3.6). Ovicell hyperstomial, presumably cleithral. Ooecium formed by the distal autozooid. Ectooecium smooth, with a longitudinal median elevated carina (Figs. 2.1, 2.2, 2.6, 3.6). A single kenozooid with costate frontal shield numbering 13 costae was observed (Fig. 2.4). Ancestrula not seen.

Etymology.-From the Latin profundus, alluding to its deep-water distribution.

Remarks.-Specimens from Capo Milazzo and Scoppo are very similar in general appearance, including the occurrence of some irregularly polygonal autozooids with a somewhat trifurcate 

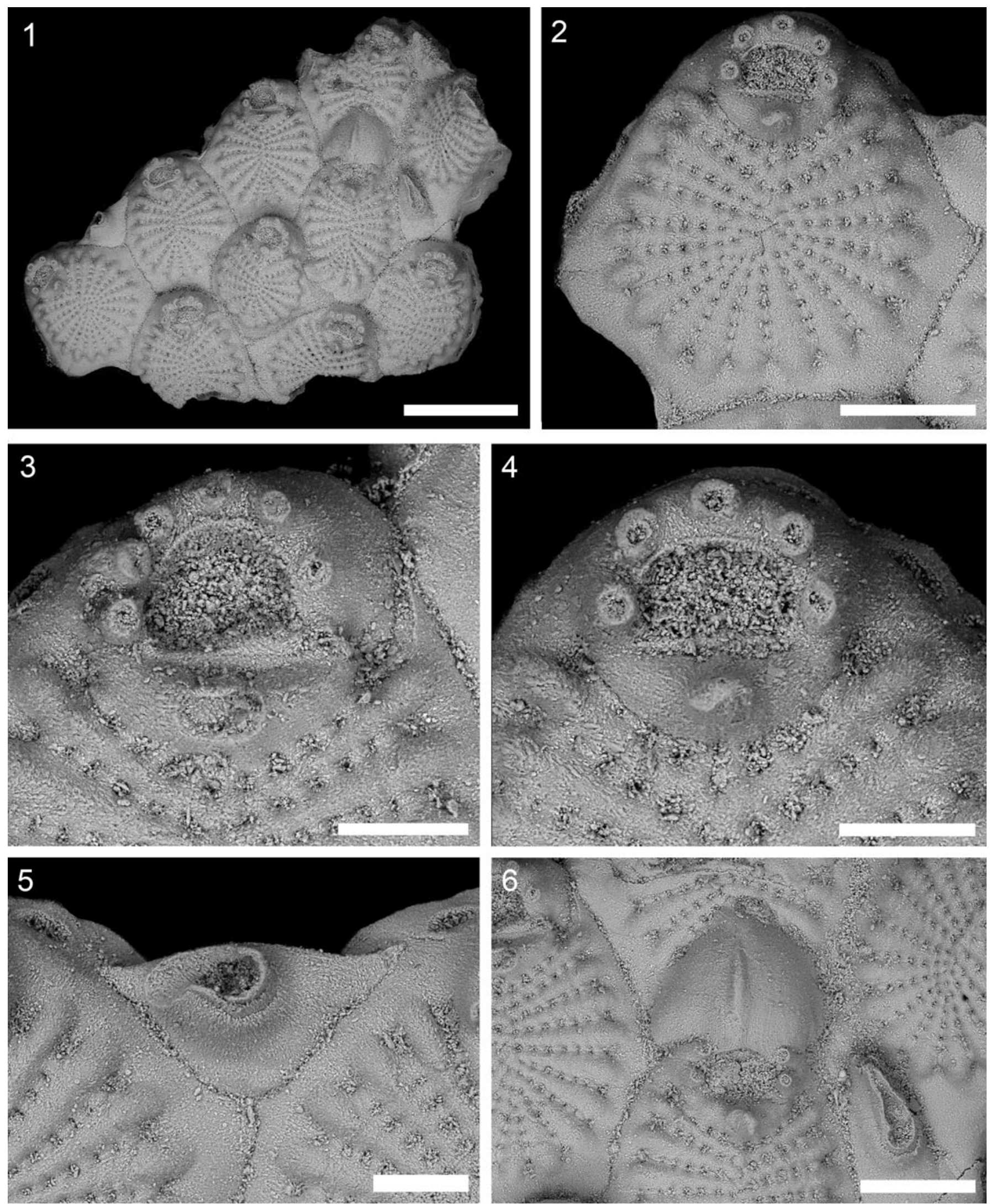

Figure 3. Cribrilaria profunda $\mathrm{n}$. sp., Scoppo, sample 24 top, early Calabrian, MNN19b-19c biozones, PMC. B27.10.10.2019c, paratype. (1) The largest fragment; (2) general view of an autozooid; (3) close-up of an orifice with unusual L/W ratio and seven oral spine bases; (4) orifice with five oral spine bases; (5) colony margin showing basal pore-chambers and interzooidal avicularium; (6) ovicellate zooid, avicularium, and ooecium showing longitudinal carina. Scale bars: (1) $500 \mu \mathrm{m}$; (2,6) $200 \mu \mathrm{m} ;(\mathbf{3 - 5}) 100 \mu \mathrm{m}$. 
Table 1. Measurements (in $\mu \mathrm{m}$ ) of Cribrilaria profunda n. sp. Abbreviations: L: length; W: width.

\begin{tabular}{llc}
\hline Species & \multicolumn{1}{c}{ Cribrilaria profunda $\mathrm{n} . \mathrm{sp}}$. \\
\cline { 2 - 3 } Locality & \multicolumn{1}{c}{ Capo Milazzo } & \multicolumn{1}{c}{ Scoppo } \\
\hline Number of costae & $17-25 ; 21 \pm 2(\mathrm{~N}=14)$ & $14-19 ; 17 \pm 1(\mathrm{~N}=12)$ \\
Zooid length & $422-750 ; 640 \pm 85(\mathrm{~N}=14)$ & $491-711 ; 622 \pm 64(\mathrm{~N}=12)$ \\
Zooid width & $271-676 ; 495 \pm 108(\mathrm{~N}=14)$ & $447-735 ; 522 \pm 85(\mathrm{~N}=12)$ \\
L/W & 1.29 & 1.19 \\
Proximal gymnocyst length & $60-189 ; 96 \pm 32(\mathrm{~N}=14)$ & $70-246 ; 112 \pm 50(\mathrm{~N}=10)$ \\
Costate shield length & $299-640 ; 407 \pm 79(\mathrm{~N}=14)$ & $294-442 ; 358 \pm 45(\mathrm{~N}=12)$ \\
Costate shield width & $300-584 ; 450 \pm 71(\mathrm{~N}=14)$ & $364-586 ; 423 \pm 61(\mathrm{~N}=12)$ \\
Orifice length & $92-97 ; 95 \pm 4(\mathrm{~N}=2)$ & $73-95 ; 81 \pm 8(\mathrm{~N}=8)$ \\
Orifice width & $130-144 ; 137 \pm 10(\mathrm{~N}=2)$ & $115-134 ; 126 \pm 7(\mathrm{~N}=8)$ \\
Number of articulated oral spines & $5(4$ if ovicellate $)$ & $5-7(4$ if ovicellate) \\
Ooecium length & $225-285 ; 261 \pm 27(\mathrm{~N}=4)$ & $235-253 ; 244 \pm 24(\mathrm{~N}=2)$ \\
Ooecium width & $252-303 ; 271 \pm 24(\mathrm{~N}=4)$ & $286-320 ; 303 \pm 24(\mathrm{~N}=2)$ \\
Ovicellate orifice length & $81-94 ; 86 \pm 7(\mathrm{~N}=3)$ & 93 \\
Ovicellate orifice width & $138-148 ; 142 \pm 5(\mathrm{~N}=3)$ & 128 \\
Interzooidal avicularium rostrum length & $225-333 ; 263 \pm 35(\mathrm{~N}=12)$ & $135-180 ; 158 \pm 32(\mathrm{~N}=2)$ \\
Interzooidal avicularium rostrum width & $70-149 ; 109 \pm 20(\mathrm{~N}=12)$ & $57-64 ; 61 \pm 5(\mathrm{~N}=2)$ \\
Interzooidal avicularium cystid length & $261-396 ; 336 \pm 69(\mathrm{~N}=3)$ & $273-323 ; 304 \pm 27(\mathrm{~N}=3)$ \\
Interzooidal avicularium cystid width & $236-406 ; 295 \pm 95(\mathrm{~N}=3)$ & $154-386 ; 238 \pm 129(\mathrm{~N}=3)$ \\
Kenozooid length & 346 & Not observed \\
Kenozooid width & 339 & Not observed \\
\hline
\end{tabular}

suture in the costate shield. Measurements also largely overlap, although Capo Milazzo material shows more variability. Yet, some specimens from Scoppo show a slightly convex costate shield with fewer costae, a more raised suboral prominence, and more (occasionally 6-7) oral spine bases. Variability in the number of oral spines within the same species is known in other cribrilinids, such as Cribrilaria pseudoradiata Harmelin and Aristegui, 1988. Specimens reported as Cribrilaria scripta (Reuss, 1848) by Harmelin and Aristegui (1988) and Harmelin and d'Hondt (1993) share their characters with the Capo Milazzo material and are here considered conspecific (see below).

Cribrilaria profunda n. sp. is very similar to the Recent $C$. saginata Winston, 2005 from off Bahia Honda (Cuba) (Winston, 2005) and the Bahama Bank (Rosso et al., 2018). However, $C$. saginata differs in having a distinctly more extensive proximal gymnocyst, a shorter and squatter orifice (orifice length/orifice width $0.42-0.55$ in $C$. saginata vs. $0.64-0.69$ in $C$. profunda n. sp.), five constant oral spines, and carinated suboral costae. Hincks (1884), and later Neviani (1900), also suggested conspecificity between $C$. saginata, as $C$. radiata (Moll, 1803) from Florida, and the middle Miocene (Langhian) Lepralia elegantissima Seguenza, 1880 from southern Calabria (Italy), which is, however, extremely unlikely owing to the great geographic and temporal distance between the two populations. In addition, the only illustration available for L. elegantissima (Seguenza, 1880, pl. 8, fig. 11) is a drawing showing a very distinctive morphology for this species, with ovoidal zooids having a wide and prominent frontal median keel, and seemingly 3-5 suboral tubercles alternating with lacunae.

Cribrilaria scripta and C. radiata, although similar in appearance to $C$. profunda n. sp., have smaller zooidal dimensions and larger interzooidal avicularia, and four oral spines occur in most zooids in the latter species (Harmelin, 1970; Bishop and Househam, 1987). Recent specimens of $C$. scripta sensu Harmelin and Aristegui (1988) from deep waters of the Ibero-Moroccan Bay and Gibraltar Strait, are here attributed to $C$. profunda n. sp. based on the measurements, the presence of generally five oral spines, and presence of a robust and smooth pair of suboral costae forming a median prominence.

In addition, specimens from the early Messinian of Carboneras (SE Spain) identified by J.-G. Harmelin as Puellina (Cribrilaria) scripta and mentioned in Barrier et al. (1992), without description or illustrations, might belong to C. profunda $\mathrm{n} . \mathrm{sp}$.

The Recent Cribrilaria pseudoradiata from the upper bathyal Atlanto-Mediterranean region is also similar to C. profunda $\mathrm{n}$. sp., but has smaller dimensions and lacks interzooidal avicularia.

Cribrilaria profunda n. sp. could possibly correspond to Lepralia planicosta Seguenza, 1880, a cribrimorph species reported from Plio-Pleistocene sediments of the Messina Strait area. Seguenza (1880) distinguished his species from C. scripta, adducing that autozooids were irregularly shaped, with a flat costate shield consisting of several costae, as in C. profunda n. sp. Unfortunately, Lepralia planicosta, supposedly corresponding to Lepralia scripta sensu Manzoni (1875) from the early Pliocene of Castrocaro, was not figured and the type material was lost in 1908 during the Messina earthquake. We refrain from selecting our material as the neotype of L. planicosta because the original description of this species seems insufficient to ensure their conspecificity, and the type localities, although geographically close, are not exactly the same, and neither are the geologic horizons. Seguenza (1880) abstained from illustrating his new species and referred to drawings of L. scripta sensu Manzoni (1875, figs. 25, 25a). Manzoni's specimens, held in the collection of the Museo di Storia Naturale, Geologia e Paleontologia of Florence, should be located and examined before selecting a neotype for this species.

\section{Genus Glabrilaria Bishop and Househam, 1987}

Type species.-Puellina pedunculata Gautier, 1956, by original designation. 

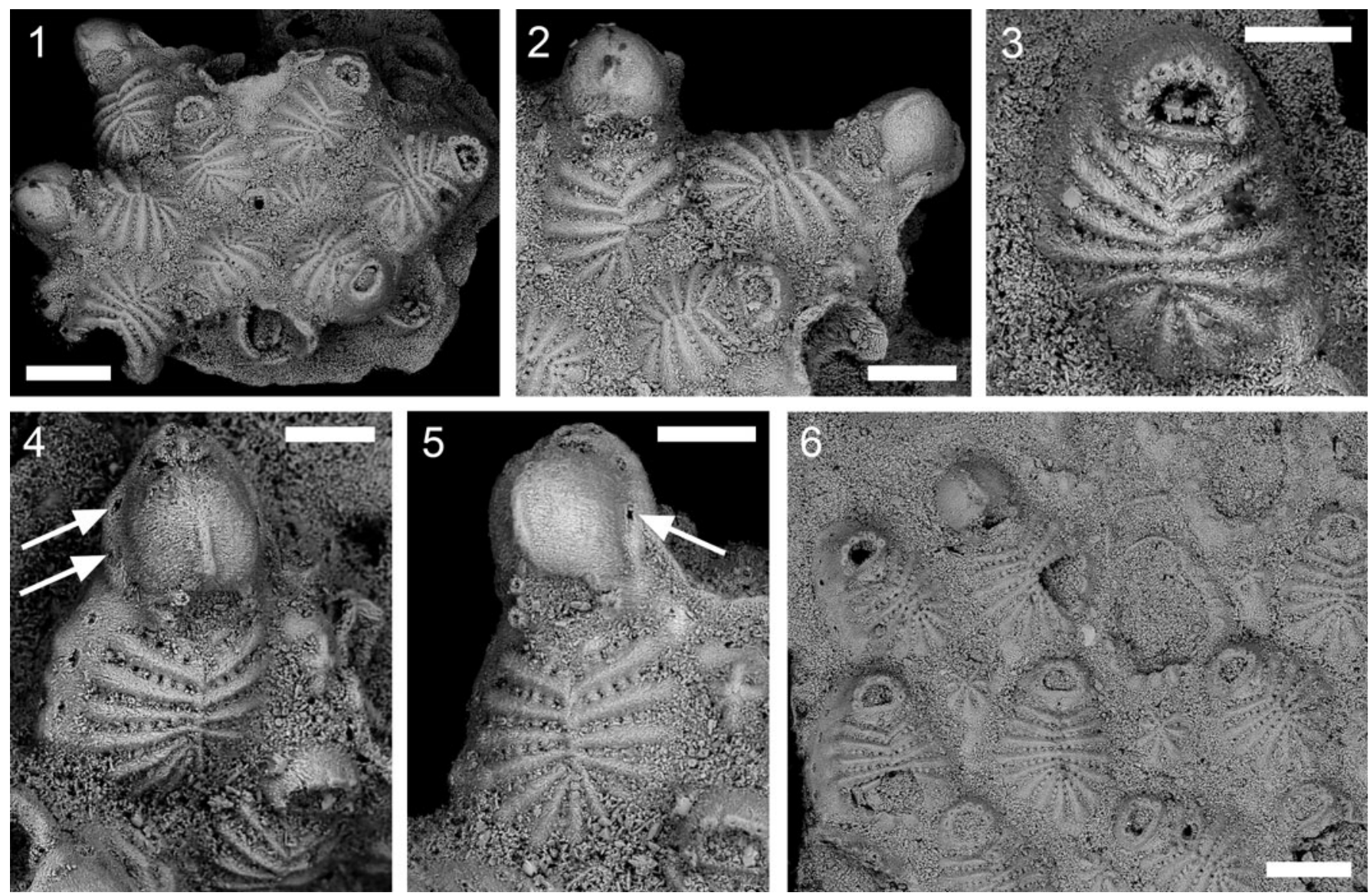

Figure 4. Glabrilaria cf. G. pedunculata Gautier, 1956, Capo Milazzo, Gelasian, Rosso Collection collective code PMC I. Pl. B.81a. (1-5) Cala Sant'Antonino center, sample 2015: (1) small fertile colony, with autozooids radiating from an apparent central ancestrula, seemingly regenerated as a miniature autozooid; (2) close-up of the three zooids on the top left of $(\mathbf{1})$; note the carinate ooecia; $(\mathbf{3})$ frontal view of autozooid with the transversely D-shaped orifice, seven oral spines, and a recrystallized suboral area; $(\mathbf{4 , 5})$ inclined views of an ovicellate zooid with four oral spines and ooecium formed by the distal kenozooid with small costal shield; arrows indicate the basal pore chambers potentially producing the avicularia lateral to the ovicell; (6) Cala Sant'Antonino center, sample 17 (2000), part of a large worn colony on a bioclast; abundant kenozooids with eight costae are seen between autozooids. Scale bars: (1, 2, 6) $200 \mu \mathrm{m} ;(\mathbf{3 - 5}) 100 \mu \mathrm{m}$.

Glabrilaria cf. G. pedunculata (Gautier, 1956) Figure 4; Table 2 cf. 1966

cf. 1970
Colletosia pedunculata; Prenant and Bobin, p. 596, fig. 207 III.

Cribrilaria pedunculata; Harmelin, p. 93, fig. lg, h, pl. 2, fig. 6 .

cf. 1956 Puellina pedunculata Gautier, p. 203, fig. 20.

Table 2. Measurements (in $\mu \mathrm{m}$ ) of Glabrilaria cf. G. pedunculata Gautier, 1956 and Glabrilaria transversocarinata $\mathrm{n}$. sp. L: length; W: width.

\begin{tabular}{|c|c|c|}
\hline $\begin{array}{l}\text { Species } \\
\text { Locality }\end{array}$ & $\begin{array}{c}\text { Glabrilaria cf. G.pedunculata (Gautier, 1956) } \\
\text { Capo Milazzo }\end{array}$ & $\begin{array}{l}\text { Glabrilaria transversocarinata } \mathrm{n} . \mathrm{sp} . \\
\text { Scoppo }\end{array}$ \\
\hline Number of costae & $13-17 ; 15 \pm 1(\mathrm{~N}=11)$ & $14-16 ; 15 \pm 1(\mathrm{~N}=10)$ \\
\hline Zooid length & $252-425 ; 337 \pm 67(\mathrm{~N}=10)$ & $407-457 ; 436 \pm 23(\mathrm{~N}=5)$ \\
\hline Zooid width & $211-323 ; 263 \pm 37(\mathrm{~N}=10)$ & $271-337 ; 302 \pm 27(\mathrm{~N}=5)$ \\
\hline $\mathrm{L} / \mathrm{W}$ & 1.28 & 1.44 \\
\hline Proximal gymnocyst length & narrow and sloping & narrow and sloping, proximal tip \\
\hline Costate shield length & $166-257 ; 201 \pm 28(\mathrm{~N}=10)$ & $227-268 ; 250 \pm 19(\mathrm{~N}=5)$ \\
\hline Costate shield width & $192-277 ; 238 \pm 31(\mathrm{~N}=10)$ & $244-264 ; 254 \pm 9(\mathrm{~N}=5)$ \\
\hline Orifice length & $46-56 ; 50 \pm 3(\mathrm{~N}=7)$ & $45-70 ; 59 \pm 9(\mathrm{~N}=4)$ \\
\hline Orifice width & $69-79 ; 74 \pm 4(\mathrm{~N}=7)$ & $63-99 ; 83 \pm 12(\mathrm{~N}=4)$ \\
\hline Number of articulated oral spines & 7 (4 on ovicellate ones) & 6 (4 on ovicellate ones) \\
\hline Ooecium length & $134-148 ; 139 \pm 8(\mathrm{~N}=3)$ & $139-165 ; 151 \pm 11(\mathrm{~N}=4)$ \\
\hline Ooecium width & $159-185 ; 170 \pm 13(\mathrm{~N}=3)$ & $153-240 ; 194 \pm 19(\mathrm{~N}=4)$ \\
\hline Ooecium length with kenozooid & 197 & $186-213 ; 200 \pm 19(\mathrm{~N}=2)$ \\
\hline Ooecium width with kenozooid & 195 & $199-265 ; 232 \pm 47(\mathrm{~N}=2)$ \\
\hline Ovicellate orifice length & $44-47 ; 46 \pm 2(\mathrm{~N}=2)$ & 60 \\
\hline Ovicellate orifice width & $80-86 ; 83 \pm 4(\mathrm{~N}=2)$ & 74 \\
\hline Kenozooid length & $108-173 ; 119 \pm 28(\mathrm{~N}=4)$ & 92 \\
\hline Kenozooid width & $94-144 ; 103 \pm 24(\mathrm{~N}=4)$ & 78 \\
\hline
\end{tabular}


cf. 1987 Puellina (Glabrilaria) pedunculata; Bishop and Househam, figs. 95-97, tab. 13.

cf. 1988 Puellina (Glabrilaria) pedunculata; Harmelin, p. 31, figs. 9-11.

cf. 2013a Puellina (Glabrilaria) pedunculata; Rosso et al., tab. 17.1.

cf. 2015 Puellina (Glabrilaria) pedunculata; Sanfilippo et al., tab. 2, fig. $5 f$.

cf. 2019a Glabrilaria pedunculata; Rosso et al., fig. 5e, f.

Holotype--MNHN-IB-2008-10384, Grand Conclu de Riou (Golfe de Marseille), Mediterranean, Recent.

Occurrence.-Glabrilaria pedunculata is an endemic Mediterranean species, widespread throughout the basin, from the Gulf of Lion to the Aegean Sea. Its presence in the Atlantic is restricted to areas swept by Mediterranean outflow water (Harmelin and d'Hondt, 1992). It has been reported from: (1) shallow-water submarine caves in the Provençal area (Harmelin, 1969, 1970, 1988, 2003), in the Ionian sea (Rosso et al., 2013a, b; Sanfilippo et al., 2015) and Aegean sea (Crete: Harmelin, 1988; Lesvos: Rosso et al., 2019a); (2) cryptic microhabitats from shallow waters (Harmelin, 2003), mid-shelf coralligenous cliffs, and outer shelf "Coralligène de Plateau," at 100-140 m depth off Lybia and near Santorini (Harmelin, 1988); and (3) at bathyal depths, $\sim 700 \mathrm{~m}$ in the Sicily Strait (Harmelin, 1979, 1988), 280 $\mathrm{m}$ in the southern Adriatic Sea (D'Onghia et al., 2015), and 500 $\mathrm{m}$ at Leuca, northeastern Ionian Sea (Mastrototaro et al., 2010), usually associated with cold-water coral habitats. Specimens from the Gelasian of Sicily represent the first fossil record for this species, suggesting its persistence, at least in deep-water settings, in the Mediterranean since the early Pleistocene.

Description.-Colony encrusting, multiserial, unilaminar (Fig. 4.1, 4.6), the largest specimen including at least 50 zooids. Zooids oval, longer than wide ( $\mathrm{L} / \mathrm{W}=1.28$ ), convex, outlined by furrows filled by incipient re-crystallization (Fig. 4). Interzooidal communication through basal pore-chambers, more than 10 visible only in some marginal zooids, with longitudinally elongate windows $\sim 10 \times 20 \mu \mathrm{m}$ (Fig. 4.4). Gymnocyst narrow, steeply sloping. Costate frontal shield oval and extensive, formed by 13-17 (including suboral) wedge-shaped, prominent costae, $27-45 \mu \mathrm{m}$ wide at the base, converging towards the midline and forming a slightly raised carina (Fig. 4.4, 4.5). Costae joined by regularly spaced intercostal bridges leaving 6-7 slit-like intercostal pores, $\sim 7-8 \mu \mathrm{m}$ long (Fig. 4.5). Only four intercostal spaces occur proximally to the suboral pair of costae, which are flat and merge at the midline forming a triangular shelf, possibly leaving a single round pore (Fig. 4.3, 4.6). Orifice transversely D-shaped (Fig. 4.1, 4.3, 4.6), marked by a raised rim, provided with 6-7 closely spaced, articulated oral spines (Fig. 4.1, 4.3), four persisting in ovicellate zooids (Fig. 4.2, 4.5). Ovicells hyperstomial, presumably cleithral. Ooecium formed by distal kenozooid, with frontally visible small costate shield consisting of three costae (Fig. 4.4); ectooecium smooth, with elevated longitudinal carina (Fig. 4.2, 4.4, 4.5). Avicularia not observed. Abundant small kenozooids recorded in larger colonies, interspersed between autozooids, seemingly polygonal, with boundaries obliterated by recrystallisation, with extensive gymnocyst and costate frontal shield of 6-8 costae (Fig. 4.6). The only ancestrula found seemingly regenerated as a miniature autozooid (Fig. 4.1).

Materials.-Rosso-Collection, collective code: PMC I. Pl. B.81a: Capo Milazzo Peninsula: Cala Sant'Antonino center: sample 2015: three specimens; sample 17 (2000): one specimen; Punta Mazza: sample 4: two specimens; sample 5: one specimen.

Remarks. - The available specimens are worn and recrystallized, preventing recognition of some diagnostic characters. However, the morphology and morphometrics of autozooids, ooecia, and kenozooids are closely reminiscent of Glabrilaria pedunculata Gautier, 1956, although with a few small differences. The present-day Mediterranean species invariably shows six oral spines and two median pores in the triangular shelf distal to the suboral costae (Bishop and Househam, 1987, fig. 97; Harmelin, 1988, fig. 17a, c; Rosso et al., 2019a, fig. 5e, f). However, both the variability in the number of oral spines and the presence/absence of median pores are considered to be in the range of intraspecific variability in cribrilinids (e.g., C. pseudoradiata Harmelin and Aristegui, 1988 and G. orientalis Harmelin, 1988). The longstalked (=pedunculate) avicularia, originating from basal pore chambers in both autozooids and kenozooids, which are typical of G. pedunculata, were not observed in our fossil specimens. This is likely a taphonomic bias, because such avicularia can be easily detached even in living colonies, as observed in Glabrilaria hirsuta Rosso in Rosso et al., 2018 from the Bahama Bank. In our fossil specimens, zooidal boundaries are mostly covered by neomorphic calcite crystals that prevent the detection of the basal pore chambers from which the pedunculate avicularia are budded. However, in Figure 4.4 and 4.5 (see arrows) the pores potentially producing the avicularia lateral to the ovicell are visible.

Seven oral spines were described in Glabrilaria corbula Bishop and Househam, 1987 and Glabrilaria orientalis lusitanica Harmelin, 1988, two closely related extant species reported from the Atlanto-Mediterranean region and the Gibraltar Strait area, respectively. However, the former species shows an ooecium that is formed by a distal kenozooid which is not distinguishable in frontal view, has 4-6 costae-like ridges arranged in a radial pattern, a flatter autozooidal shield with somewhat carinate costae that are sometimes with a pelma, and two large pores in the suboral shelf (Bishop and Househam, 1987; Harmelin, 1988), while the latter species lacks midline pores in the suboral shelf (Harmelin, 1988). Glabrilaria orientalis lusitanica also has semi-erect interzooidal avicularia (Harmelin, 1988) backed against the ooecium. Six to seven oral spines also occur in Glabrilaria africana (Hayward and Cook, 1983), but this species has numerous variably sized pores in the suboral shelf in addition to semi-erect avicularia associated with the ooecium and squeezed between autozooids.

Glabrilaria transversocarinata new species Figure 5; Table 2

Holotype.-PMC. B28.10.10.2019a: colony consisting of $\sim 20$ autozooids, some ovicellate. Scoppo, sample 24 top, early Calabrian, MNN19b-19c biozones. 

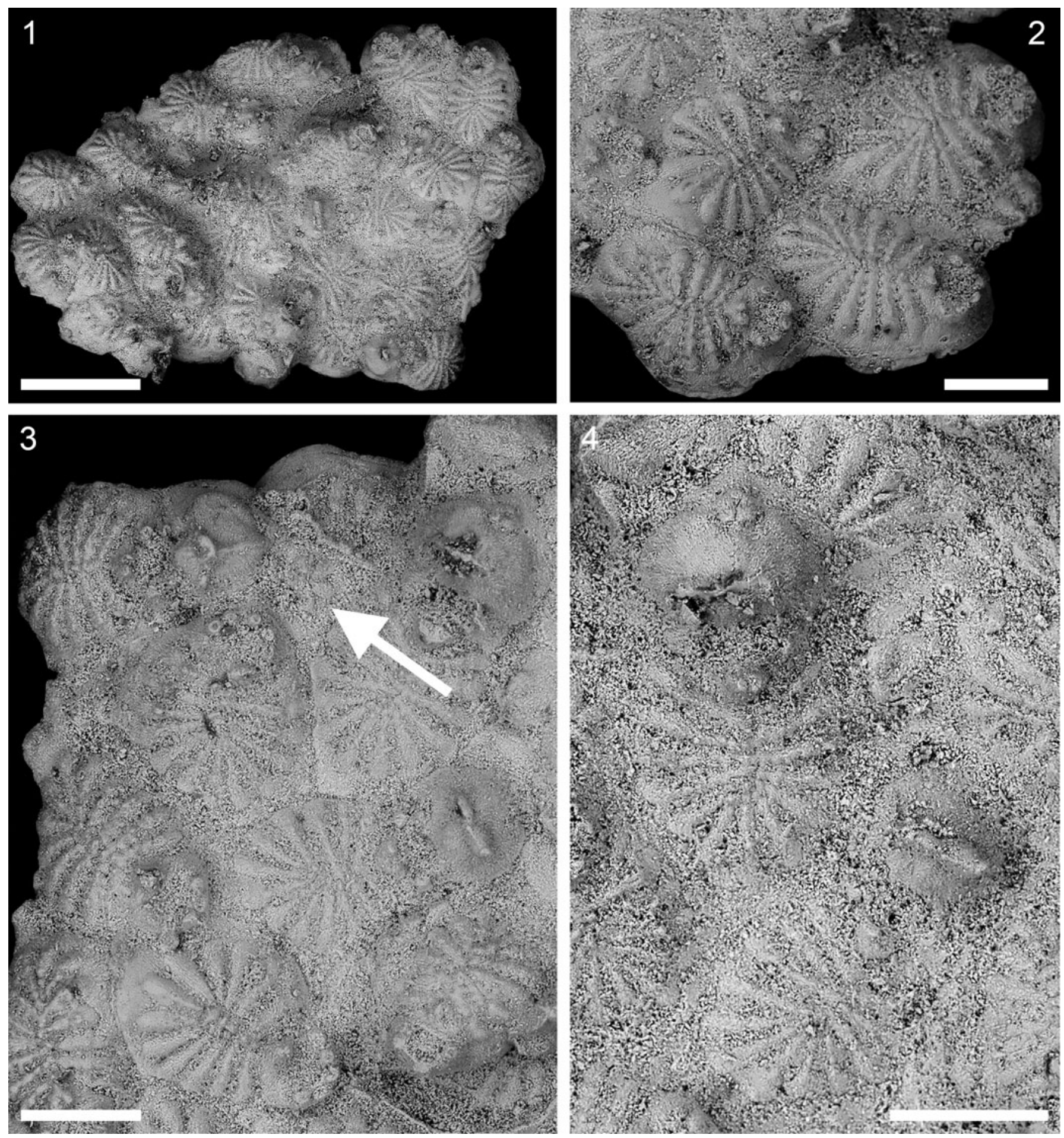

Figure 5. Glabrilaria transversocarinata n. sp., Scoppo, sample 24 top, early Calabrian, MNN19b-19c biozones, PMC. B28.10.10.2019a, holotype. (1) The largest specimen consisting of partly superimposed colony layers; (2) group of zooids at the colony margin showing intercostal spaces; (3) cluster of ovicellate and non-ovicellate zooids; arrow indicates a small kenozooid with five costae (note the elevated bases of oral spines and the transversely oriented crest located in the middle of the ooecium and the possible persistence of four oral spines); (4) two ovicellate zooids (note the prominent bifid suboral mucro and flat shield composed of somewhat tuberculate costae). Scale bars: (1) $500 \mu \mathrm{m}$; (2-4) $200 \mu \mathrm{m}$.

Paratype.-PMC. B28.10.10.2019b: small colony fragment including seven autozooids, two ovicellate. Scoppo: sample 24 top, early Calabrian, MNN19b-19c biozones.

Diagnosis. - Colony encrusting, multiserial. Autozooids convex. Gymnocyst narrow. Frontal shield consisting of 12-14 prominent and tuberculate costae with 3-7 intercostal spaces. Suboral pair of costae forming a bifid mucro. Orifice transversely D-shaped with six oral spines, four persisting in ovicellate zooids. Ovicells subimmersed. Ooecium formed by distal kenozooid, surface smooth, with transverse rib. Avicularia not observed. Kenozooids rare. 
Occurrence.-Only known from the early Calabrian of Scoppo, Messina.

Description.-Colony encrusting, multiserial, unilaminar, but including superimposed lobes (Fig. 5.1), the largest observed fragment consisting of $\sim 20$ zooids. Zooids oval, longer than wide $(\mathrm{L} / \mathrm{W}=1.44)$, convex, the outline hidden by incipient recrystallization (Fig. 5.4). Interzooidal communication through basal pore-chambers visible in some peripheral zooids, with slightly longitudinally elongate windows $\sim 21 \times 18 \mu \mathrm{m}$ (Fig. 5.2). Gymnocyst very narrow, except for proximal and, occasionally, lateral extensions wedged between neighboring zooids (Fig. 5.2, 5.3). Frontal shield oval and extensive, formed by 14-16 (including suboral) wedgeshaped, prominent, tuberculate costae, $26-47 \mu \mathrm{m}$ wide at the base, converging towards the midline (Fig. 5.2-5.4). Costae joined by intercostal bridges apparently leaving 6-7 intercostal pores (Fig. 5.2), seemingly reduced to 3-4 proximally to the suboral pair of costae. These are shorter and more robust than the other costae and raised at the midline, forming a bifid mucro (Fig. 5.2, 5.3). Orifice transversely D-shaped, provided with six closely spaced, articulated oral spines (Fig. 5.2), four persisting in ovicellate zooids (Fig. 5.3, 5.4). Ovicells subimmersed. Ooecium formed by the distal kenozooid, with frontally visible costate (4-5 costae) shield and distal band of gymnocyst (Fig. 5.3, 5.4); ooecium with prominent, transverse, straight to slightly arched rib possibly with protruding spikes (lost) (Fig. 5.3, 5.4); an additional thinner and lower longitudinal carina was observed in a single ooecium (Fig. 5.3). Avicularia not observed. Only one kenozooid was observed. It was small, polygonal, with a relatively narrow gymnocyst and costate frontal shield of five radial costae (Fig. 5.3). Ancestrula not observed.

Etymology.-From the Latin transversus, meaning transversely placed, and carina alluding to the typical median crest of the ooecium.

Remarks.-The co-occurrence of a prominent transverse ridge on the ooecium and a bifid suboral mucro is distinctive of this species. Ooecia with a transverse ridge are known in a few species only. One is the extant Glabrilaria hirsuta Rosso in Rosso et al., 2018 from the Bahama Bank, in which the ridge is, however, very arched to subtriangular and equipped with prominent spine-like processes (Rosso et al., 2018). Furthermore, in G. hirsuta, the number of oral spines (six, four persisting in ovicellate zooids) occasionally increases to seven, the costae have more obvious spine-like processes at the periphery of the frontal shield, the suboral costae form a transverse spiny crest proximal to the orifice, and kenozooids arranged in rows or clusters are very common (Rosso et al., 2018). In the extant Glabrilaria cristata (Harmelin, 1978) from the Hyères and Meteor banks south of the Azores, the ooecial ridge is extremely protruding and situated more proximally towards the orifice, contributing to form a sort of spiny collar around the orifice together with the second pair of suboral costae. These costae bear cockscomb-like spines that are still present but smaller than those on the other pairs
(Harmelin, 1978). Oral spines are invariably seven in this species.

Occasionally, transverse ornamentation has been reported in the ooecia of other cribrilinid genera. A succession of ribs adds to a longitudinal carina in Puellina cassidainsis Harmelin, 1984 from the 3PP submarine cave in the Mediterranean French coast (see Harmelin, 1984, fig. 7b). A cruciform pattern can develop in the ooecia of Cribrilaria macaronensis (Harmelin, 2006), and transverse ridges or wrinkles in Cribrilaria atlantis (Harmelin, 2006), both species previously assigned to Puellina (see Harmelin, 2006, fig. 1).

Measurements of Glabrilaria transversocarinata n. sp. generally overlap with those of $G$. cf. G. pedunculata from Capo Milazzo (Table 2), but tend towards the higher values, sometimes exceeding the upper limit. The only exception is the size of the kenozooid, which seems to be smaller, although only based on a single measurement. However, morphological differences, including the number of oral spines, shape of costae, suboral lacuna and ooecia, and the rarity of kenozooids, distinguish the two species.

The two colony fragments available are detached from the substratum, a common feature for bryozoan specimens found in the Capo Milazzo "yellow marl." This may indicate either that the substratum was organic or that selective aragonitic dissolution took place during/before fossilization.

\section{Genus Figularia Jullien, 1886}

Type species.—Lepralia figularis Johnston, 1847, by original designation.

Amended diagnosis.-Colony commonly encrusting, but erect, fan-shaped, or developing erect lobes in some species. Autozooids with variably developed gymnocyst, usually wider proximally; costate shield formed by few to numerous (up to 30) costae, each bearing a pelma (circular to drop-shaped or transversely elongated) varying in size and position. Orifice with well-developed poster and condyles, dimorphic and typically larger in ovicellate zooids. Oral spines absent. Avicularia, when present, vicarious, elongate, and often spatulate, with complete crossbar. Ovicells hyperstomial or subimmersed, cleithral. Ooecium formed by the distal autozooid or kenozooid (sometimes in the same colony), bilobate, consisting of two very large, modified costae, arched and meeting in the midline to form a suture and/or carina; each costa with a wide fenestra. Interzooidal communication via mural pore chambers in the transverse walls and multiporous septula in the lateral walls. Ancestrula only observed in the type species, wider than autozooids, subcircular, with narrow gymnocyst encircling an extensive opesia with differentiated orifice; no spines.

Remarks. - The finding of a new species having morphological skeletal features fitting into the genus Figularia Jullien, 1886, but characterized by erect colony form and a very distinctive and large ooecium formed by a distal kenozooid, led to the examination of species currently placed in this genus (Tables 3, 4). 
Table 3. List of species currently belonging to the genus Figularia with description of the main skeletal morphological characters. These species conform to the diagnosis of the genus. Abbreviations: Dim Or, Dimorphic orifice; Distr, Stratigraphic distribution; E, Eocene; M, Miocene; N, number; O, Oligocene; Orig, Origin; P, Pliocene; Pl, Pleistocene; R, Recent; ZL: autozooidal length; ZW: autozooidal width; Transv. =

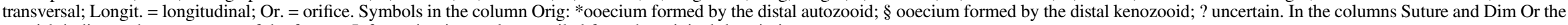
asterisk indicates the occurrence of the feature. Information is mostly compiled from the original descriptions.

\begin{tabular}{|c|c|c|c|c|c|c|c|c|c|c|c|}
\hline \multirow[b]{2}{*}{ Species } & \multirow[b]{2}{*}{ Distr } & \multirow[b]{2}{*}{ Costate shield } & \multirow[b]{2}{*}{$\mathrm{N}$ of costae } & \multirow[b]{2}{*}{ Intercostal pores } & \multirow[b]{2}{*}{ Pelmata } & \multicolumn{3}{|c|}{ Ooecium } & \multirow[b]{2}{*}{ Dim Or } & \multirow{2}{*}{$\begin{array}{l}\text { Vicarious } \\
\text { avicularia }\end{array}$} & \multirow[b]{2}{*}{ Additional notes } \\
\hline & & & & & & Orig & Fenestrae & Suture & & & \\
\hline $\begin{array}{l}\text { Figularia arnouldi } \\
\text { Buge, } 1956\end{array}$ & $P$ & Extensive & 12 & numerous & 1 & $* \S$ & Transv. triangular & *carina & & $\begin{array}{l}\text { Spathulate } \\
\text { with bar }\end{array}$ & $\begin{array}{l}\text { Ooecium also formed by } \\
\text { vicarius avicularium. }\end{array}$ \\
\hline $\begin{array}{l}\text { F. carinata } \\
\text { (Waters, 1887) }\end{array}$ & $\mathrm{R}$ & $2 / 3 \mathrm{ZL} ;<1 / 2 \mathrm{ZW}$ & $10-12$ & fissure & 1 (slit-like) & $*$ & $\begin{array}{l}\text { Transv. } \\
\text { drop-shaped to } \\
\text { elliptical }\end{array}$ & * & * & $\begin{array}{l}\text { Spathulate } \\
\text { with bar }\end{array}$ & $\begin{array}{l}\text { Fenestrae undulate, slit-like in } \\
\text { Gordon (1984). Possibly } \\
\text { two different species. }\end{array}$ \\
\hline $\begin{array}{l}\text { F. clithridiata } \\
\text { (Waters, 1887) }\end{array}$ & $\mathrm{R}$ & 1/2 ZL; 1/2 ZW & $7-10$ & $?$ & 1 (oval) & $\S$ & $\begin{array}{l}\text { Transv. } \\
\text { drop-shaped }\end{array}$ & & & Duckfeet-shaped & $\begin{array}{l}\text { Ooecium with peripheral } \\
\text { semicircle of pelma } \\
\text { seemingly belonging to the } \\
\text { distal kenozooid. }\end{array}$ \\
\hline $\begin{array}{l}\text { F. dimorpha } \\
\text { Figuerola et al., } 2018\end{array}$ & $\mathrm{R}$ & 2/3 ZL; 1/2 ZW & 16 & numerous & 1 & $*$ & $\begin{array}{l}\text { Transv. oval to } \\
\text { pear-shaped }\end{array}$ & *carina & $*$ & Ogival with bar & \\
\hline $\begin{array}{l}\text { F. figularis } \\
\quad \text { (Johnston, 1847) }\end{array}$ & $? \mathrm{M}-\mathrm{R}$ & 2/3 ZL; 4/5 ZW & $9-13$ & $\sim 5$ & 1 (circular) & $* \S$ & $\begin{array}{l}\text { Transv. } \\
\text { drop-shaped to } \\
\text { irregularly oval }\end{array}$ & * & & $\begin{array}{l}\text { Spathulate } \\
\text { with bar }\end{array}$ & $\begin{array}{l}\text { Specimens in Souto et al. } \\
\text { (2014) possibly different } \\
\text { species. }\end{array}$ \\
\hline $\begin{array}{l}\text { F. fissa } \\
\text { (Hincks, 1880) }\end{array}$ & $\mathrm{R}$ & $1 / 3 \mathrm{ZL} ; 1 / 2 \mathrm{ZW}$ & $8-10$ & 1 (triangular) & 1 (circular) & $*$ & Transv. crescentic & $*$ & & $\begin{array}{l}\text { Spoon-like } \\
\text { with bar }\end{array}$ & $\begin{array}{l}\text { Likely a species complex (see } \\
\text { Harmer, 1926, figs 20-23 } \\
\text { and Ryland and Hayward, } \\
\text { 1992). }\end{array}$ \\
\hline $\begin{array}{l}\text { F. fissurata } \\
\text { Canu and Bassler, } 1929\end{array}$ & $\mathrm{R}$ & $1 / 2 \mathrm{ZL} ; 2 / 3 \mathrm{ZW}$ & $3-12$ & fissure & 1 (circular) & $*$ & Transv. crescentic & $*$ & $*$ & $\begin{array}{l}\text { Spoon-like } \\
\text { with bar }\end{array}$ & \\
\hline $\begin{array}{l}\text { F. haueri } \\
\text { (Reuss, 1848) }\end{array}$ & M & Extensive & $14-18$ & numerous & $\begin{array}{l}\text { Not mentioned or } \\
\text { visible in fig. }\end{array}$ & $*$ & $\begin{array}{l}\text { Not mentioned or } \\
\text { visible in fig. }\end{array}$ & *arina & & Absent & $\begin{array}{l}\text { Seemingly only differing from } \\
\text { F. figularis by some } \\
\text { morphometrics (see } \\
\text { Berning, 2006) }\end{array}$ \\
\hline $\begin{array}{l}\text { F. hilli } \\
\text { (Osburn, 1950) }\end{array}$ & $\mathrm{R}$ & 3/4 ZL; 4/5 ZW & $5-7$ & 1-2 (slit-like) & 1 (drop-shaped) & $*$ & Transv. oval & $*$ & $*$ & Absent & $\begin{array}{l}\text { Ooecium including a pair of } \\
\text { proximo-lateral costae. }\end{array}$ \\
\hline $\begin{array}{l}\text { F. japonica } \\
\text { Silén, } 1941\end{array}$ & $\mathrm{R}$ & 3/4 ZL; 4/5 ZW & $11-13$ & 1-3 (circular) & 1 (drop-shaped) & $*$ & $\begin{array}{c}2 \text { pairs, transv. } \\
\text { triangular }\end{array}$ & * & $*$ & $\begin{array}{l}\text { Duckfeet-shaped } \\
\text { with bar }\end{array}$ & $\begin{array}{l}\text { 7-10 costae in Yang et al., } \\
2018 \text {. }\end{array}$ \\
\hline $\begin{array}{l}\text { F. mernae } \\
\text { Uttley and Bullivant, } 1972\end{array}$ & $\mathrm{R}$ & $2 / 3 \mathrm{ZL} ; 1 / 2 \mathrm{ZW}$ & $12-18$ & 1 (slit-like) & 1 (circular) & * & $\begin{array}{l}\text { Longit. } \\
\text { drop-shaped }\end{array}$ & * & * & $\begin{array}{r}\text { Lanceolate } \\
\text { with bar }\end{array}$ & \\
\hline $\begin{array}{l}\text { F. pelmatifera } \\
\text { Gordon, } 1984\end{array}$ & $\mathrm{R}$ & 3/4 ZL; 3/4 ZW & $24-30$ & $\begin{array}{r}\text { fissure }+1-2 \\
\quad \text { (elliptical) }\end{array}$ & 1 (elliptical) & $*$ & $\begin{array}{l}\text { Longit. } \\
\text { drop-shaped }\end{array}$ & * & * & Not observed & \\
\hline $\begin{array}{l}\text { F. philomela } \\
\text { (Busk, 1884) }\end{array}$ & $\mathrm{R}$ & Extensive & $14-16$ & numerous & $\begin{array}{l}\text { Not mentioned or } \\
\text { visible in figs. }\end{array}$ & $*$ & $\begin{array}{l}\text { Diagonal elliptical } \\
\text { to transv. } \\
\text { drop-shaped }\end{array}$ & *carina & & Spathulate & $\begin{array}{l}\text { Plastic colony morphology } \\
\text { including an encrusting } \\
\text { phase (var. adnata) and } \\
\text { bilaminar erect parts. }\end{array}$ \\
\hline $\begin{array}{l}\text { F. rhodanica } \\
\quad \mathrm{Li}, 1990\end{array}$ & M & Extensive & $14-20$ & 2 & $\begin{array}{l}\text { Not mentioned or } \\
\text { visible in fig. }\end{array}$ & * & $\begin{array}{l}\text { Not mentioned or } \\
\text { visible in fig. }\end{array}$ & *carina & & $\begin{array}{l}\text { Spoon-like } \\
\text { with bar }\end{array}$ & \\
\hline $\begin{array}{l}\text { F. speciosa } \\
\text { (Hincks, 1881) }\end{array}$ & $\mathrm{R}$ & 4/5 ZL; 3/4 ZW & $12-18$ & 3 (slit-like) & 1 (slit-like) & $*$ & Longit. slit-like & *carina & $*$ & Absent & \\
\hline F. spectabilis $\mathrm{n}$. sp. & $\mathrm{Pl}$ & 3/4 ZL; 3/4 ZW & $8-13$ & 3-4? (subcircular) & 1 (drop-shaped) & $\S$ & $\begin{array}{l}\text { Large } \\
\text { quadrangular }\end{array}$ & * & * & $\begin{array}{l}\text { Slightly } \\
\text { spathulate }\end{array}$ & $\begin{array}{l}\text { Colony erect, flabelliform, } \\
\text { very large ooecium. }\end{array}$ \\
\hline $\begin{array}{l}\text { F. tenuicosta } \\
\text { (MacGillivray, 1895) }\end{array}$ & $\mathrm{M}, ? \mathrm{R}$ & $2 / 3 \mathrm{ZL} ;>1 / 2 \mathrm{ZW}$ & $19-20$ & 1 (slit-like) & 1 (slit-like) & $*$ & $\begin{array}{l}\text { Longit. } \\
\text { drop-shaped }\end{array}$ & * & $*$ & Duckfeet-shaped & \\
\hline $\begin{array}{l}\text { F. triangula } \\
\quad \text { Powell, 1967b }\end{array}$ & $\mathrm{R}$ & $2 / 3 \mathrm{ZL} ;<1 / 3 \mathrm{ZW}$ & $12-14$ & 1 (slit-like) & Absent & $?$ & Transv. slit-like & $*$ & & Not observed & \\
\hline
\end{tabular}


Table 4. List of doubtful species currently attributed to the genus Figularia. New combinations are suggested for two species, while attribution of the remaining species awaits examination of the type material. Abbreviations: Dim Or, Dimorphic orifice; Distr, Stratigraphic distribution; M, Miocene; N, number; Orig, Origin. P, Pliocene; Pl, Pleistocene; R, Recent; ZL: autozooidal length; ZW: autozooidal width. Symbols in the column Orig: *ooecium formed by the distal autozooid; § ooecium formed by the distal kenozooid, ? uncertain. In the columns Sutue and Dim Or he ast

\begin{tabular}{|c|c|c|c|c|c|c|c|c|c|c|c|c|}
\hline \multirow[b]{2}{*}{ Species } & \multirow[b]{2}{*}{ Distr } & \multirow[b]{2}{*}{ Costate shield } & \multirow{2}{*}{$\begin{array}{l}\mathrm{N} \text { of } \\
\text { costae }\end{array}$} & \multirow{2}{*}{$\begin{array}{l}\text { Intercostal } \\
\text { pores }\end{array}$} & \multirow[b]{2}{*}{ Pelmata } & \multicolumn{3}{|c|}{ Ooecium } & \multirow[b]{2}{*}{ Dim Or } & \multirow{2}{*}{$\begin{array}{l}\text { Vicarious } \\
\text { avicularia }\end{array}$} & \multirow{2}{*}{$\begin{array}{c}\text { New } \\
\text { combination }\end{array}$} & \multirow[b]{2}{*}{ Additional notes } \\
\hline & & & & & & $\overline{\text { Orig }}$ & Fenestrae & $\overline{\text { Suture }}$ & & & & \\
\hline $\begin{array}{l}\text { Figularia ampla } \\
\text { Canu and Bassler, } 1928\end{array}$ & $\mathrm{R}$ & 2/3 ZL; 1/3 ZW & 10 & fissure & none & * & Absent & *carina & & Not mentioned & & $\begin{array}{l}\text { Frontal shield densely } \\
\text { pseudoporous }\end{array}$ \\
\hline $\begin{array}{l}\text { F. capitifera } \\
\text { Canu and Bassler, } 1929\end{array}$ & $\mathrm{R}$ & $\begin{array}{l}\text { Vestigial, } \\
\text { suboral }\end{array}$ & $2+2$ & & 1 (elliptical) & * & Single, central & & & Spathulate & $\begin{array}{l}\text { Vitrimurella } \\
\text { capitifera }\end{array}$ & $\begin{array}{l}\text { Frontal shield and ooecium with } \\
\text { massive pseudopores }\end{array}$ \\
\hline $\begin{array}{l}\text { F. contraria } \\
\text { Lagaaij, } 1963\end{array}$ & $\mathrm{R}$ & 2/3 ZL; $1 / 2 \mathrm{ZW}$ & $8-11$ & 2 & 1 (circular) & $\S$ & $\begin{array}{l}\text { Two pairs of small } \\
\text { membranous areas }\end{array}$ & *carina & * & Not observed & & $\begin{array}{l}\text { Ovicell subimmersed. Ooecium } \\
\text { with a pair of small oval } \\
\text { membranous areas centrally. } \\
\text { Two more membraneous areas } \\
\text { are situated on the ectooecium } \\
\text { laterally }\end{array}$ \\
\hline $\begin{array}{l}\text { F.? crassicostulata } \\
\text { Canu and Bassler, } 1920\end{array}$ & E & Extensive & $16-20$ & $3-6$ & $\begin{array}{l}\text { Not mentioned or } \\
\text { visible in fig. }\end{array}$ & * & Transv. crescentic & & & $\begin{array}{l}\text { Spathulate, } \\
\text { ?no bar }\end{array}$ & & \\
\hline $\begin{array}{l}\text { F. duvergieri } \\
\quad \text { Bassler, } 1936\end{array}$ & M & $2 / 3 \mathrm{ZL} ;=\mathrm{ZW}$ & $14-16$ & $4-6$ & $\begin{array}{l}\text { Not mentioned or } \\
\text { visible in fig. }\end{array}$ & * & Absent/not visible & * & & $\begin{array}{l}\text { Elliptical } \\
\text { with bar }\end{array}$ & & $\begin{array}{l}\text { Orifice with finely denticulate } \\
\text { anter. }\end{array}$ \\
\hline $\begin{array}{l}\text { F. echinoides } \\
\text { Brown, } 1952\end{array}$ & $\mathrm{O}$ & Extensive & $22-24$ & numerous & $2-3$ spine-like & & Ovicells not observed/Ab & & & $\begin{array}{l}\text { Spathulate, } \\
\text { no bar }\end{array}$ & & \\
\hline $\begin{array}{l}\text { F. jucunda } \\
\text { Canu and Bassler, } 1929\end{array}$ & $\mathrm{R}$ & 2/3 ZL; 3/5 ZW & $8-9$ & 1 (triangular) & 1 (circular) & $\S$ & $\begin{array}{l}\text { Pseudopores and/or } \\
\text { pelmatidia }\end{array}$ & *carina & * & Not observed & & $\begin{array}{l}\text { Ooecium with pseudopores and/or } \\
\text { pelmatidia }\end{array}$ \\
\hline $\begin{array}{l}\text { F. kenley } \\
\quad \text { Brown, } 1958\end{array}$ & M & $1 / 2 \mathrm{ZL} ; 4 / 5 \mathrm{ZW}$ & $14-16$ & 1 (slit-like) & $\begin{array}{l}\text { Visible/present only } \\
\text { on suboral costae? }\end{array}$ & $?$ & 2 large & *carina & & Not observed & & $\begin{array}{l}\text { Erect bilaminar; pelma only on } \\
\text { suboral costae }\end{array}$ \\
\hline $\begin{array}{l}\text { F. peltata } \\
\text { (Reuss, 1874) }\end{array}$ & M & Extensive & $15-18$ & numerous & Absent/not visible & * & Absent & & & Not mentioned & & Flat ooecium \\
\hline $\begin{array}{l}\text { F. planicostulata } \\
\text { Canu and Lecointre, } 1928\end{array}$ & $\mathrm{M}$ & Extensive & 17 & several, large & Absent/not visible & $?$ & Absent/not visible & & * & Spathulate & & Smooth ooecium. \\
\hline $\begin{array}{l}\text { F. pulcherrima } \\
\text { Tilbrook et al., } 2001\end{array}$ & $\mathrm{R}$ & $1 / 2 \mathrm{ZL} ; 1 / 2 \mathrm{ZW}$ & $9-10$ & $3-5$ & 1 (circular) & $\S$ & $\begin{array}{l}2 \text { drop-shaped, basal } \\
\text { lateral + } 2 \text { slit-like, } \\
\text { median }\end{array}$ & $*$ & & Not observed & & $\begin{array}{l}\text { Ooecium with central costate area. } \\
\text { cf. F. tahitiensis. }\end{array}$ \\
\hline $\begin{array}{l}\text { F. quaylei } \\
\quad \text { Powell, 1967a }\end{array}$ & $\mathrm{R}$ & Extensive & $10-12$ & fissure & 2 (circular) & * & $4-7$ & & & Not observed & $\begin{array}{l}\text { Hayamiellina } \\
\text { quaylei }\end{array}$ & Costate ooecium \\
\hline $\begin{array}{l}\text { F. rugosa } \\
\text { (Maplestone, 1901) }\end{array}$ & M & & & & Absent/not visible & $?$ & & & * & $\begin{array}{l}\text { Lanceolate } \\
\text { no bar }\end{array}$ & & Costate ooecium \\
\hline $\begin{array}{l}\text { F. ryukuensis } \\
\text { Kataoka, } 1961\end{array}$ & $\mathrm{Pl}$ & Extensive & $8-10$ & 1 (slit-like) & Absent/not visible & * & Pseudopores & & & Not mentioned & & $\begin{array}{l}\text { Pseudoporous ooecium with } \\
\text { ill-defined keel }\end{array}$ \\
\hline $\begin{array}{l}\text { F. tahitiensis } \\
\text { (Waters, 1923) }\end{array}$ & $\mathrm{R}$ & $2 / 3 \mathrm{ZL} ; 1 / 2 \mathrm{ZW}$ & 11 & numerous & 1 (circular) & $\S$ & $\begin{array}{l}2 \text { drop-shaped, basal } \\
\text { lateral }+2 \text { slit-like, } \\
\text { median }\end{array}$ & * & & Not figured & & $\begin{array}{l}\text { Ooecium with central costate area. } \\
\text { cf. F. pulcherrima. }\end{array}$ \\
\hline
\end{tabular}



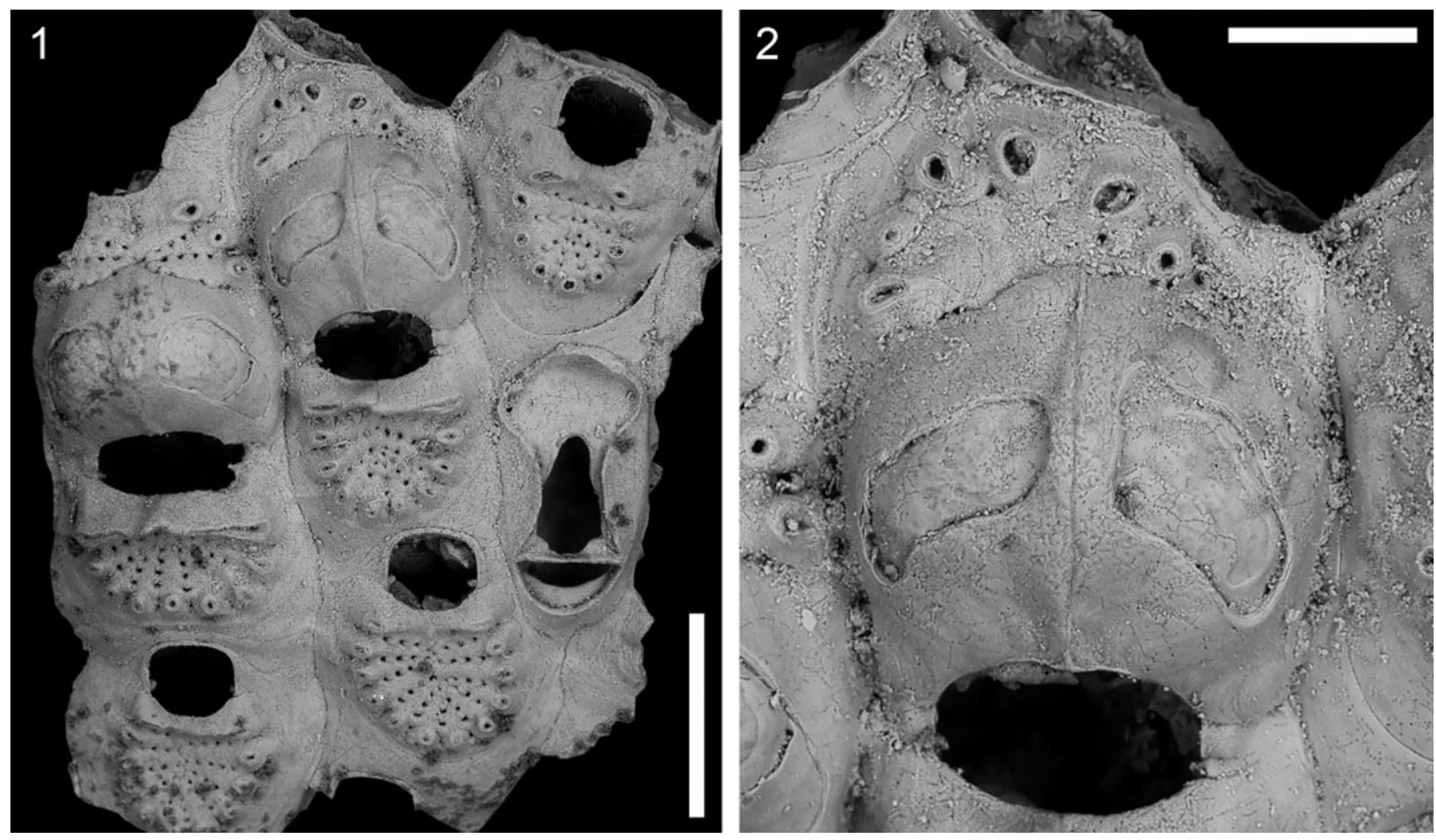

Figure 6. Figularia figularis (Johnston, 1847), Southern Tyrrhenian Sea, Rosso collection PMC. I. Pl. B.71.b, Apollo Bank sample. (1) Small fragment consisting of five autozooids, two ovicellate, and a vicarious avicularium; left ooecium is formed by the distal autoooid, right by the distal kenozooid with frontally visible costal shield; (2) close-up of the ooecium formed by the distal kenozooid. Scale bars: (1) $500 \mu \mathrm{m}$; (2) $200 \mu \mathrm{m}$.

Figularia was introduced by Jullien (1886, p. 608) who designated Lepralia figularis Johnston, 1847, an AtlantoMediterranean extant species, as the type species of the genus, and included an additional fossil species Lepralia elegantissima based on the unique drawing available (Seguenza, 1880, p. 83, pl. 8, fig. 11). This latter species, depicted with oral spine bases, is more likely to be a species of Cribrilaria (see also Remarks on Cribrilaria profunda n. sp.). Oral spines are absent in the type species F. figularis (see Soule et al., 1995, fig. 45C), as well as in all living and fossil specimens found to date (e.g., Figs. 6, 7). The absence of oral spines has also been reported almost consistently in the diagnosis of the genus, with only a few exceptions (e.g., Gordon, 1984). Further diagnostic characters include a complete crossbar in the vicarious avicularia, and the presence of large, symmetrical ectooecial fenestrae and a median carina in the ooecium (see Soule et al., 1995; Hayward and Ryland, 1998; Kukliński and Barnes, 2009; Yang et al., 2018).

The erect colony-form has never been mentioned in the generic diagnosis before. However, Busk (1884, p. 132) described Figularia philomela as "free; erect or decumbent (hemescharan)." Subsequently, Hayward and Cook (1979, p. 76) found a bilaminar fragment of $F$. philomela interpreted as part of an erect foliaceous colony possibly arising from an encrusting phase (var. adnata of Busk, 1884). Gordon (1989, p. 15, 16) recorded the occasional occurrence of an erect bilamellar lobe, arising from the adjacent encrusting zooids, in a colony of Figularia mernae Uttley and Bullivant, 1972 from
Puysegur Bank, off the South Island of New Zealand. The fanshaped colonies of the newly discovered Figularia species from Capo Milazzo, although often fragmentary (Fig. 8), show a configuration comparable to that observed in F. mernae, with basal zooids elongated and arranged in back-to-back adjacent pairs (Fig. 8.1, 8.2, 8.6). The lack of a costate frontal shield, with no obvious evidence of breakage, in several proximal/basal zooids, suggests that simplified polymorphs, reminiscent of those in Corbulipora MacGillivray, 1895 (see Bock and Cook, 2001) may occur. However, the raising of the erect fan-shaped portions from an encrusting phase is doubtful until encrusting colonies, or at least isolated encrusting zooids, are found.

The ooecium in Figularia is generally described as bivalved/bifenestrate (Ostrovsky, 2013). In F. figularis, the prominent bilobate ooecium is formed by the distal autozooid, with two costae meeting in the midline leaving a suture and/or forming a slightly raised carina; each costa bearing a large, irregularly shaped and transversely elongate fenestra (membranous area in non-cleaned specimens). The colony fragment of F. figularis from the Apollo Bank (Tyrrhenian Sea, Mediterranean) shows that ooecia formed by the distal kenozooid can co-occur in the same colony in this species (Fig. 6). Though uncommonly reported, and here recorded in F. figularis for the first time, the co-occurrence of ooecia produced by the distal autozooid and kenozooid is known in other cribrilinids, such as Cribrilina punctata (Hassall, 1841), "Puellina" harmeri Ristedt, 1985 (see also discussion in Rosso et al., 2018), Cribrilaria innominata (Couch, 1844) (see Chimenz Gusso et al., 2014), 

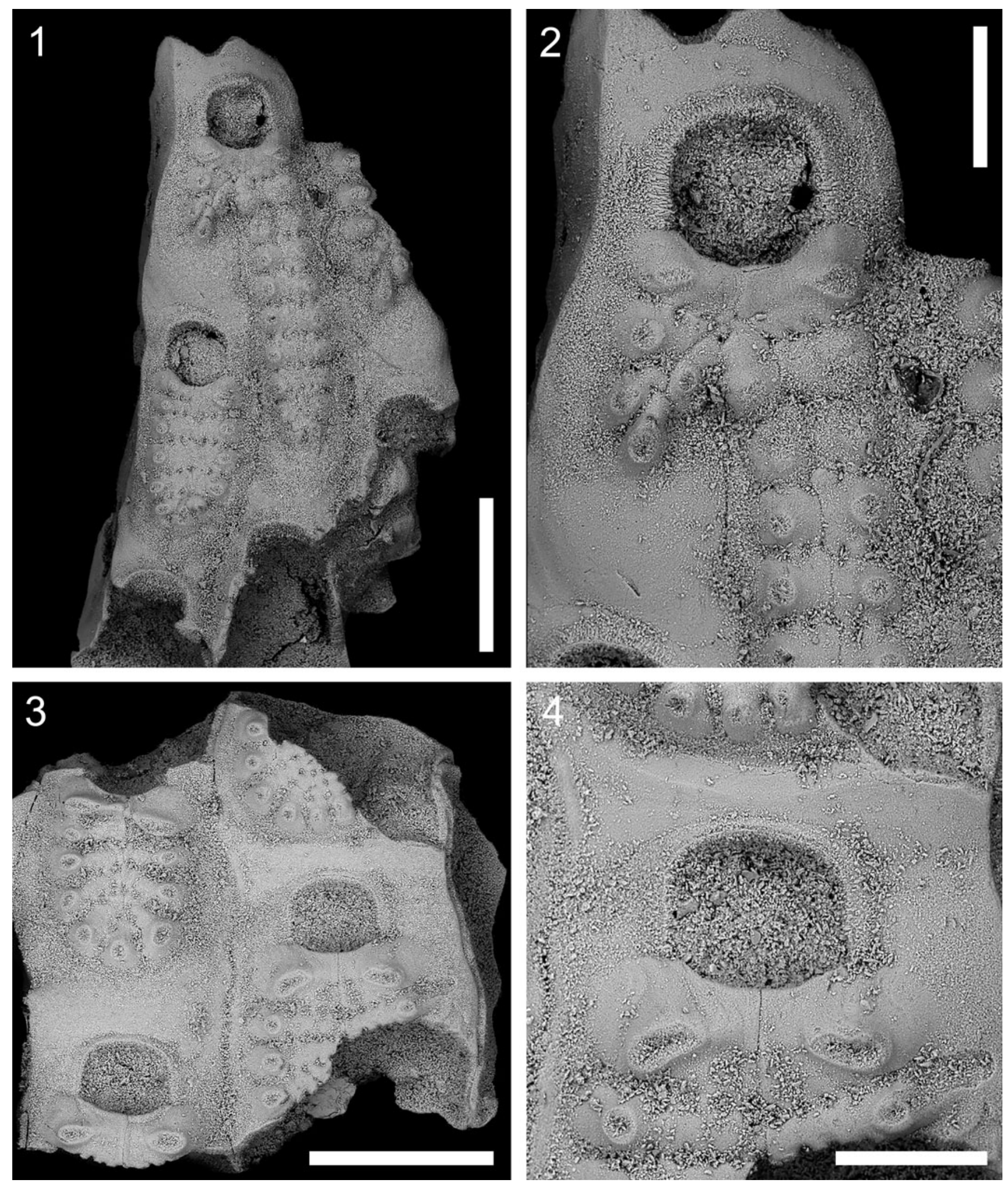

Figure 7. Figularia figularis (Johnston, 1847), Scoppo, sample 24 top, early Calabrian, MNN19b-19c biozones, Rosso collection PMC I. Pl. B.71.c. (1) Fragment with few autozooids (note the teratologic autozooid); (2) close-up of the distal half of the teratologic autozooid shown in (1); (3) fragment with four, incomplete autozooids; (4) close-up of the orifice. Scale bars: $(\mathbf{1}, \mathbf{3}) 500 \mu \mathrm{m} ;(\mathbf{2}, \mathbf{4}) 200 \mu \mathrm{m}$. 


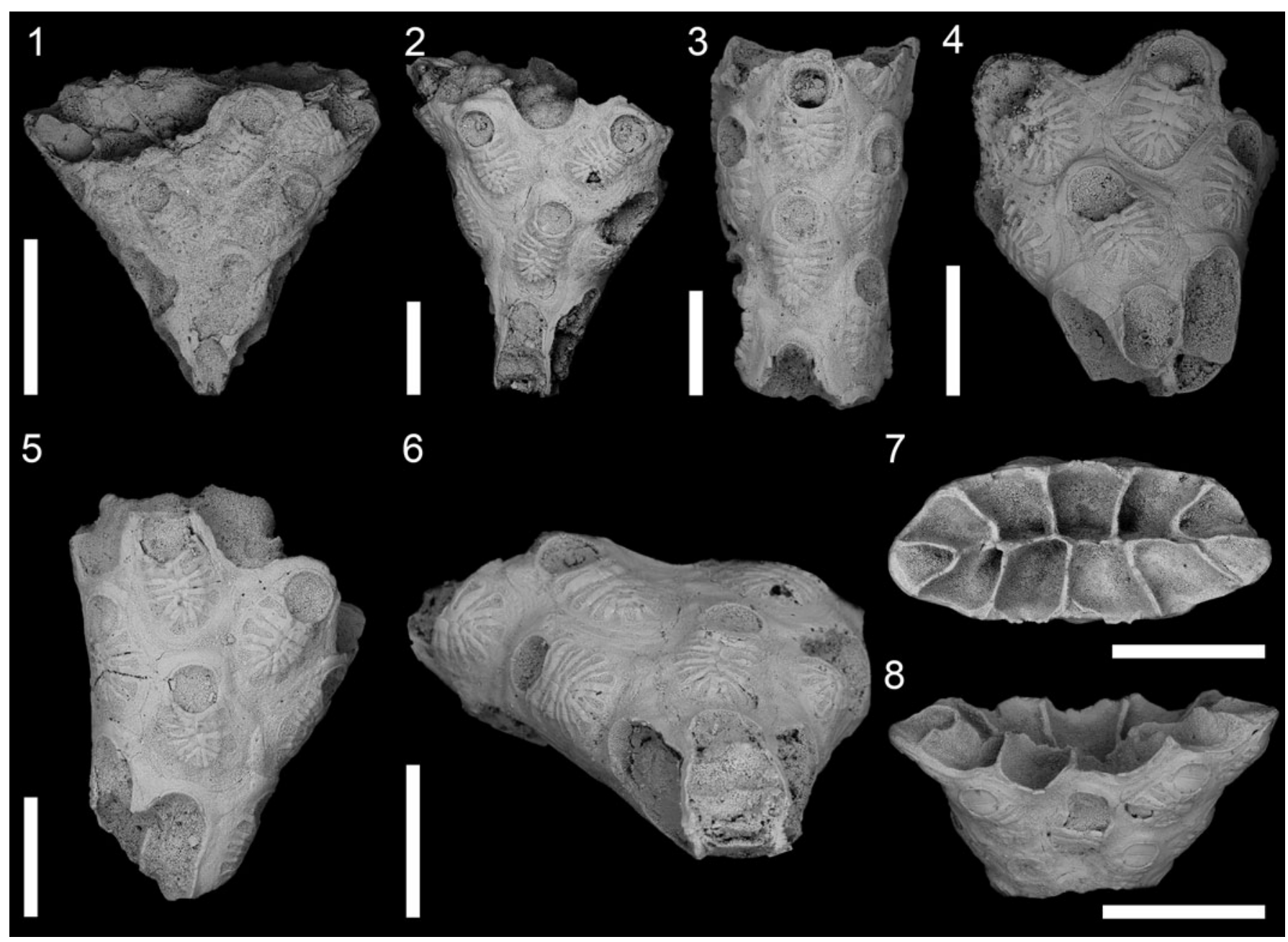

Figure 8. Figularia spectabilis n. sp., Capo Milazzo, sample Cala Sant'Antonino center, 2015, Gelasian, PMC. B22. 5.4.2015.b, paratypes, colony morphology. $(\mathbf{1}, \mathbf{2})$ Lateral view of two fan-shaped colony fragments with thin cylindrical proximal base; $(\mathbf{3})$ side view of a narrow ribbon-like fragment; $(\mathbf{4}, \mathbf{5})$ inclined proximal view and lateral view of fan-shaped colony fragments with slightly diverging sides; (6) proximal view of a fan-shaped colony fragment; (7, 8) inclined distal and top view of a fan-shaped colony fragment. Scale bars: $(\mathbf{1}, \mathbf{7 , 8}) 1 \mathrm{~mm} ;(\mathbf{2 - 6}) 500 \mu \mathrm{m}$.

Puellina saldanhai Harmelin, 2001, and Puellina mikelae Harmelin, 2006. Following Rosso et al. (2018), the latter two species are here allocated to the genus Cribrilaria: Cribrilaria saldanhai (Harmelin, 2001) n. comb. and Cribrilaria mikelae (Harmelin, 2006) n. comb. Both ovicell variants sometimes may appear within the same colony (e.g., in $C$. punctata and " $P$." harmeri) indicating a developmental plasticity of this character (reviewed in Ostrovsky, 2013). A similar plasticity in ovicell formation is only known in some Calloporidae (Ostrovsky and Schäfer, 2003; Ostrovsky et al., 2009; Ostrovsky, 2013) that are presumed ancestors of cribrilinids.

The kenozooid producing the ooecium in F. figularis shows a crescent-shaped shield of short radial costae, each with a single pelma as in the autozooids, but also with a single intercostal pore (Fig. 6). The same structure is also evident in the fossil species from Capo Milazzo (Fig. 9). Ovicells with ooecia formed by the distal kenozooid also occur in other species currently assigned to this genus, based on examination of available SEM images and, to a lesser extent, drawings (see Table 3).

Ostrovsky (2013, fig. 1.28A) illustrated sectioned decalcified ovicells of $F$. figularis in which most of the brood cavity is situated in the proximal part of the distal zooid predominantly below the colony surface, thus corresponding to endozooidal type. Whether this position of the brood cavity was an effect of decalcification of the skeleton (and, thus, sagging of the originally raised ooecium) during preparation for sectioning is currently not clear, but this contradicts most descriptions showing hyperstomial ovicells in this species (see references above). Still, a degree of the brood cavity immersion may vary, and, for example, both hyperstomial and subimmersed ovicells are known within the genus Figularia, and hyperstomial, subimmersed, and endozooidal ovicells are described in the different species of Puellina (Ostrovsky, 2013). Subimmersed ovicells were present in Recent colonies of F. figularis from the Mediterranean (A. Ostrovsky, personal observations).

Ostrovsky and Taylor (2005) noted the occurrence of species of Figularia-F. clithridiata (Waters, 1887), F. tahitiensis Waters, 1923, and F. pulcherrima Tilbrook, Hayward and Gordon, 2001-having costate ooecia (see also Ostrovsky, 2002). Winston et al. (2014) remarked that the occurrence of costate ooecia in $F$. pulcherrima possibly suggests a better allocation of this species in a distinct genus. Inclusion of costae in the 

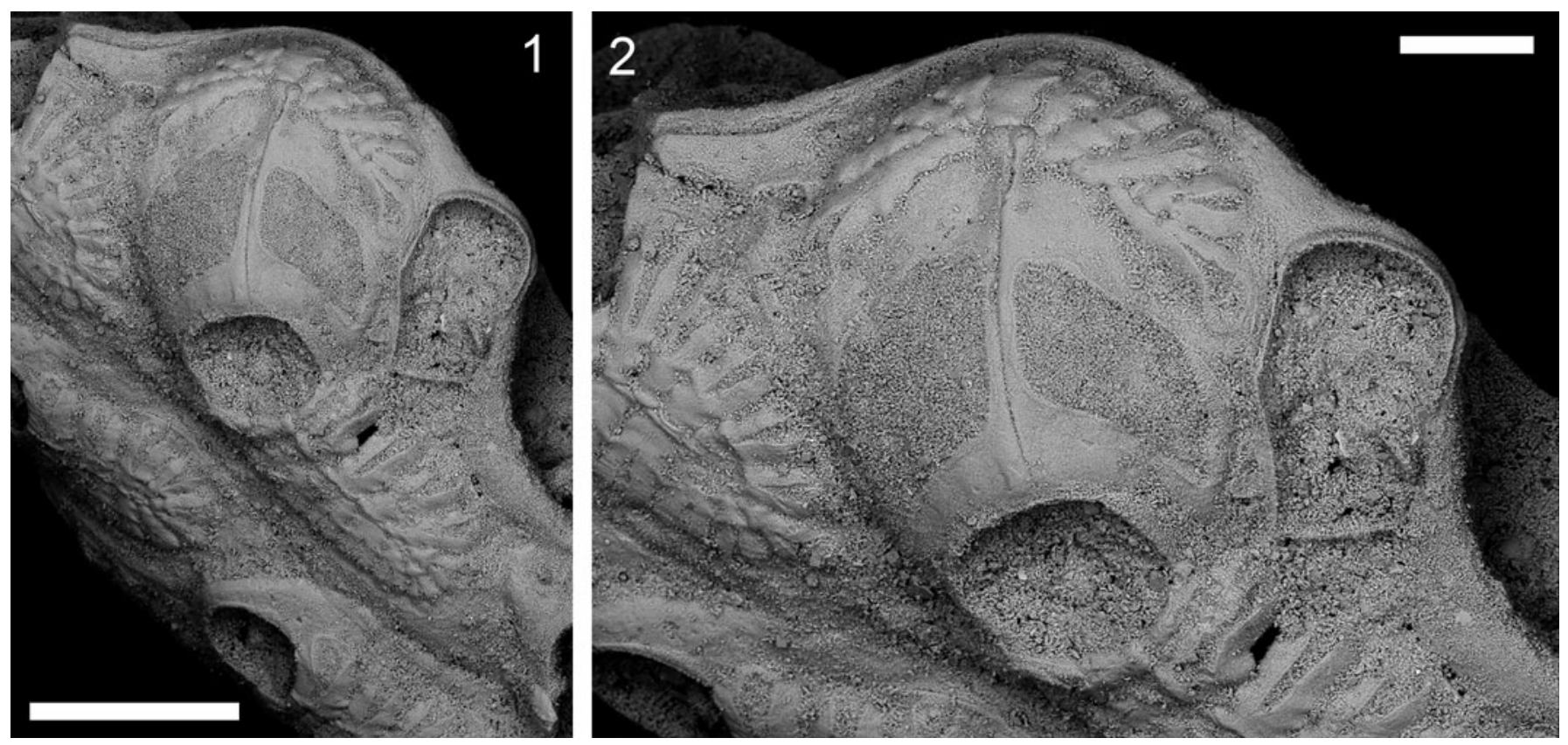

Figure 9. Figularia spectabilis n. sp., Capo Milazzo, sample Cala Sant'Antonino center, 2015, Gelasian, PMC. B22. 5.4.2015.a, holotype, ooecium. (1) Colony fragment with unique ovicellate zooid and vicarious avicularium; (2) close-up of the ovicellate zooid with ooecium formed by the distal kenozooid. Scale bars: (1) $500 \mu \mathrm{m} ;(2) 200 \mu \mathrm{m}$.

construction of the ooecium has also been observed in Figularia hilli (Osburn, 1950), with two small costae similar to those of the frontal shield added proximally to the larger ooecial halves (see Table 3).

Yang et al. (2018), while including pseudoporous ooecia in the diagnosis of Figularia, also suggested the examination of species with multiple ectooecial pseudopores in order to determine if they are genuinely congeneric. These species are here re-assigned to different genera (see also below and Table 4).

Suboral costae often differ from the other pairs. In the type species of Figularia, suboral costae merge, forming a smooth, wide shelf facing the orifice, most evident in ovicellate zooids (Fig. 6). Wide suboral costae associated with ovicellate zooids were also observed in F. rhodanica $\mathrm{Li}, 1990$. In F. pelmatifera Gordon, 1984 the suboral pair of costae develops into two lateral, divergent, spinose processes (see Gordon, 1984, pl. 19, fig. E).

A certain variability occurs in the presence/absence of pelmata in the frontal shield, and in their position along the costal length. Sometimes this variability was noted (e.g., Gordon, 1984). Nevertheless, all Figularia species lacking pelmata (i.e., not included in formal descriptions and/or undetectable in available images) are fossil, except " $F$. philomela var. adnata" (Busk, 1884), suggesting that their absence may be a preservation artefact.

The ancestrula is generally not mentioned in species descriptions to our knowledge. In the amended diagnosis, we include characters of the ancestrula for the first time, based on the ancestrula found in a colony of $F$. figularis from the Mediterranean illustrated in Rosso et al. (2019b, fig. 5C). The large size of both autozooids and ancestrula $(0.65 \times 0.67 \mathrm{~mm})$ and the absence of spines are rare and remarkable among cribrilinids, which usually have small, tatiform ancestrulae, and this may have implications on the systematics/phylogeny of this genus within the family Cribrilinidae. However, observation of ancestrulae in additional species is needed to confirm whether this morphology is constant among congeners, which has been proven not to be the case in other cheilostome genera, such as e.g., Escharina Milne Edwards, 1836 (see Berning et al., 2008).

Several species previously assigned to Figularia were recently displaced in different genera of the families Cribrilinidae and Calloporidae (e.g., Vitrimurella, Reginella Jullien, 1886, Inferusia Kukliński and Barnes, 2009, Valdemunitella Canu, 1900; see Bock and Gordon, 2020), and Jullienula Bassler, 1953 (Yang et al., 2018). Here, we suggest further displacements: both Figularia? ampla Canu and Bassler, 1928, only tentatively included in Figularia when first described, and Emballotheca? capitifera, Canu and Bassler, 1929, subsequently referred to his new genus Calyptotheca by Harmer (1957) and to Figularia by Di Martino and Taylor (2018), fit better in Vitrimurella, owing to the pseudoporous zooidal gymnocyst and ooecia, and the extremely reduced costate shield. Figularia ryukyuensis Kataoka, 1961 and F. jucunda Canu and Bassler, 1929 also need to be revised, pending examination of the type material. These species have pseudoporous ooecia formed by the distal kenozooid without a visible frontal part. Figularia duvergieri Bassler, 1936 has an unusual denticulate proximal orifice margin, and lacks costal pelmata and fenestrae in the ooecium. A detailed revision based on SEM images is needed to confirm generic allocation for these problematic species (Table 4). This issue has been partially addressed by López Gappa et al. (in press).

\section{Figularia figularis (Johnston, 1847) \\ Figures 6, 7; Table 5}

1847 Lepralia figularis Johnston, p. 314.

1966 Figularia figularis; Prenant and Bobin, p. 604, fig. 2010 I-IV, VI. 
Table 5. Measurements (in $\mu \mathrm{m}$ ) of Figularia figularis and Figularia spectabilis n. sp. *Refers to an aberrant zooid (see text for further explanation). L: length; W: width.

\begin{tabular}{|c|c|c|}
\hline $\begin{array}{l}\text { Species } \\
\text { Locality }\end{array}$ & $\begin{array}{l}\text { Figularia figularis (Johnston, 1847) } \\
\text { Scoppo }\end{array}$ & $\begin{array}{l}\text { Figularia spectabilis n. sp. } \\
\text { Capo Milazzo }\end{array}$ \\
\hline Number of costae & $10-20 ; 14 \pm 5(\mathrm{~N}=3)^{*}$ & $7-14 ; 10 \pm 2(\mathrm{~N}=18)$ \\
\hline Zooid length & 858 & $588-1057 ; 759 \pm 135(\mathrm{~N}=16)$ \\
\hline Zooid width & 402 & $319-525 ; 442 \pm 55(\mathrm{~N}=16)$ \\
\hline $\mathrm{L} / \mathrm{W}$ & 2.13 & 1.72 \\
\hline Proximal gymnocyst length & $41-111 ; 86 \pm 31(\mathrm{~N}=4)^{*}$ & $60-210 ; 114 \pm 47(\mathrm{~N}=14)$ \\
\hline Costate shield length & $455-457 ; 456 \pm 1(\mathrm{~N}=2)$ & $294-582 ; 388 \pm 93(\mathrm{~N}=14)$ \\
\hline Costate shield width & $307-396 ; 352 \pm 63(\mathrm{~N}=2)$ & $306-543 ; 378 \pm 65(\mathrm{~N}=14)$ \\
\hline Orifice length & $202-228 ; 213 \pm 12(\mathrm{~N}=4)$ & $176-292 ; 236 \pm 32(\mathrm{~N}=18)$ \\
\hline Orifice width & $202-244 ; 225 \pm 21(\mathrm{~N}=4)$ & $179-295 ; 233 \pm 31(\mathrm{~N}=18)$ \\
\hline Number of articulated oral spines & absent & absent \\
\hline Ooecium length & not observed & 702 \\
\hline Ooecium width & not observed & 730 \\
\hline Ovicellate orifice length & not observed & 297 \\
\hline Ovicellate orifice width & not observed & 323 \\
\hline Interzooidal avicularium length & not observed & $473-642 ; 566 \pm 86(\mathrm{~N}=3)$ \\
\hline Interzooidal avicularium width & not observed & $273-337 ; 298 \pm 34(\mathrm{~N}=3)$ \\
\hline
\end{tabular}

1998 Figularia figularis; Hayward and Ryland, p. 338, fig. 120, cum syn.

2002 Figularia figularis; Hayward and McKinney, p. 38, fig. 16 D-E.

2006 Figularia figularis; Berning, 2006, p. 49, pl. 3, figs. 7, 10, cum syn.

2014 Figularia figularis; Chimenz Gusso et al., p. 167, fig. $84 \mathrm{a}-\mathrm{c}$.

Holotype.-NHMUK 1847.9.16.39, English Channel, Recent.

Occurrence.-Figularia figularis is widely distributed in the Atlanto-Mediterranean area since the middle Miocene (Moissette et al., 1993; Berning, 2006). This species has been commonly reported from shelf habitats, mostly from the deep shelf, often associated with deep coralligenous facies (Di Geronimo et al., 1990; Ballesteros, 2006), and at the shelf break in both the Mediterranean (110-145 $\mathrm{m}$; see Harmelin and d'Hondt, 1992) and the eastern Atlantic as far north as the British Isles (Hayward and Ryland, 1998).

Materials.-Rosso collection PMC. I. H. B.71.b, Apollo Bank sample: two specimens, Recent; Rosso-Collection PMC I. Pl. B.71.c, Scoppo: sample 24 top: two specimens, early Calabrian, MNN19b-19c biozones.

Remarks. - Two fossil fragments were found, each consisting of a few zooids (Fig. 7). Zooidal morphological characters allow a reliable identification, even in the absence of ovicells and avicularia. Morphometrics fall within the ranges reported for this species. Inferred teratology in an autozooid resulted in a double-bifurcated frontal shield (Fig. 7.1, 7.2). This unusual feature also occurs in the type specimen of $F$. tenuicosta MacGillivray, 1895 from the middle Miocene of Victoria, Australia (Bock, 2020). Although F. figularis exhibits a certain range of morphological variability, some historical records, mostly beyond its confirmed geographical range, proved to be different species (e.g., Brown, 1952). The conspecificity of the colony found on a rock at
Armaçao de Pêra in Portugal (Souto et al., 2014) needs to be verified. This colony has an unusual triangular ooecial fenestra with narrow horizontal part and could represent a different species.

\section{Figularia spectabilis new species} Figures 8-11, Table 4

Holotype.-PMC. B22. 5.4.2015.a: bilaminar fragment including some autozooids and the only observed ovicell. Cala Sant'Antonino, sample Cala Sant' Antonino center, 2015, Gelasian.

Paratypes.-PMC. B22. 5.4.2015.b: additional 39 fragments from the same sample as the holotype, including several fan-shaped colony portions. One fragment from sample 17 (2000), Cala Sant'Antonino center.

Diagnosis.-Colony erect, bilaminar with fan-shaped fronds, the tapering proximal terminations possibly consisting of heteromorphs, likely rising from an encrusting phase. Zooidal frontal shield consisting of flat costae, each with a large, elongate drop-shaped pelma placed on its peripheral half; gymnocyst wider laterally and proximally, narrower distally, with faint striations. Vicarious avicularia elongate, spatulate, with extensive rostral palate and complete crossbar. Ovicell subimmersed, presumably cleithral. Ooecium formed by the distal kenozooid with frontally visible costate part, and consisting of two very large, wing-shaped costae merging in the midline producing a longitudinal suture, with two large fenestrae exposing wide areas of endooecium; the costae of the ooecium-producing kenozooid smaller, forming a distal, crescent-shaped crown, each costa with a small pelma.

Occurrence.-Exclusively known from early Pleistocene (Gelasian) deep-water sediments of Capo Milazzo (NE Sicily, Italy).

Description.—Available colony fragments bilaminar, fan-shaped (the largest $\sim 2 \mathrm{~mm}$ long by $3 \mathrm{~mm}$ wide); fragments diverging distally at variable angles from a subcylindrical proximal 

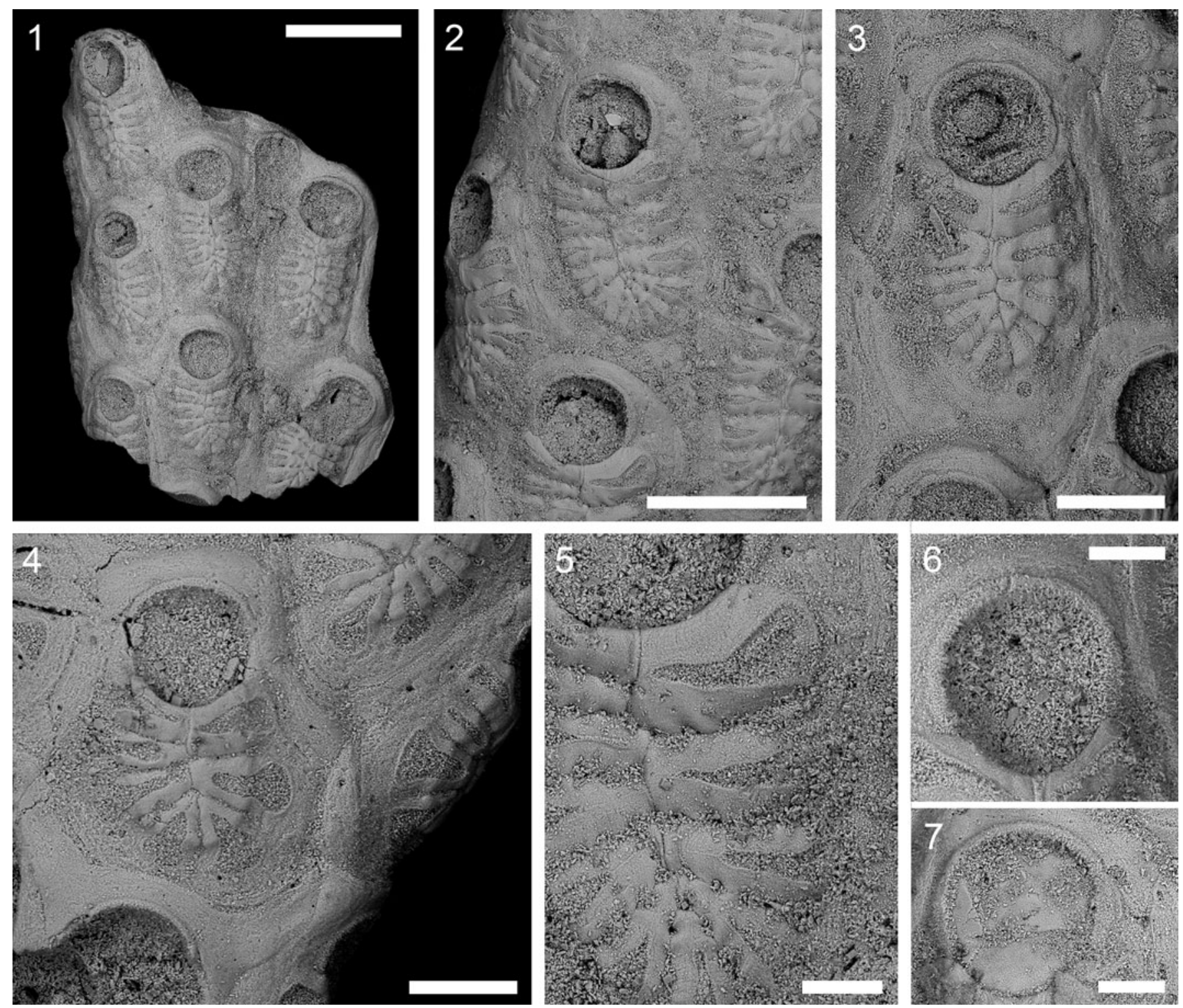

Figure 10. Figularia spectabilis n. sp., Capo Milazzo sample Cala Sant'Antonino center, 2015, Gelasian, PMC. B22. 5.4.2015.b, paratypes, autozooids. (1) Fragment of a bilaminar branch with zooids arranged in longitudinal rows and distal vicarious avicularium; (2) group of autozooids; (3) close-up of elongated autozooid with well-defined boundaries and growth lines in the gymnocyst (note the smooth texture of the costae, converging towards the midline, and the elongate pelmata); (4) wider autozooid with large wedge-shaped costae and very large drop-shaped pelmata; (5) close-up of some costae; (6) orifice; (7) orifice with closure plate or calcified operculum. Scale bars: (1, 2) $500 \mu \mathrm{m} ;(\mathbf{3 , 4}) 200 \mu \mathrm{m} ;(\mathbf{5 - 7}) 100 \mu \mathrm{m}$.

portion, consisting of four zooids arranged in back-to-back pairs (Fig. 8.1, 8.2, 8.4-8.8). Other fragments of similar size include only the edges of presumably ribbon-like colonies (Figs. 8.3, 10.1). Putative proximal heteromorphs, possibly arising from an encrusting phase and forming the basal stalk, lacking calcified frontal shield. Zooidal boundaries marked by grooves. Zooids large, about twice as long as wide $(\mathrm{L} / \mathrm{W}=1.72)$, gently arched distally, wedged proximally. Gymnocyst more extensively exposed proximally and laterally (Figs. 8.2, 8.3, 8.5, 10.1-10.4), locally obliterated by recrystallization (Fig. 10.5). Costate shield extensive ( $\sim 75 \%$ of the frontal surface), gently convex, formed by 7-14 flat and smooth costae (maximum basal width $72-111 \mu \mathrm{m}$ ), varying from short and subtriangular proximally to long and parallel sided distally; the suboral pair often the largest (Fig. 10.1-10.5). Costae defined by grooves, connected by an uncertain number of intercostal bridges, presumably 3-4 (Fig. 10.5), with small oval to subcircular intercostal pores in between. A longitudinal suture marking the costal fusion along zooidal midline (Fig. 11.1). Each costa bearing a single, elongate, drop-shaped pelma with the rounded base placed in correspondence with the base of the costa, while the acute vertex extends up to half to two thirds of costal length. Orifice oval to round, slightly longer than wide, concave proximally, gently arched distally, outlined by a rim of calcification (Fig. 10). Oral spines absent. Avicularia vicarious, infrequent, elongate and slightly asymmetrical, varying in size; rostrum long, spatulate, directed distally and slightly inclined, facing frontally (Figs. 9.1, 11); post-mandibular area short, palate wide, crossbar complete (Fig. 11.3). Ovicell subimmersed, presumably cleithral. A single observed ooecium formed by 

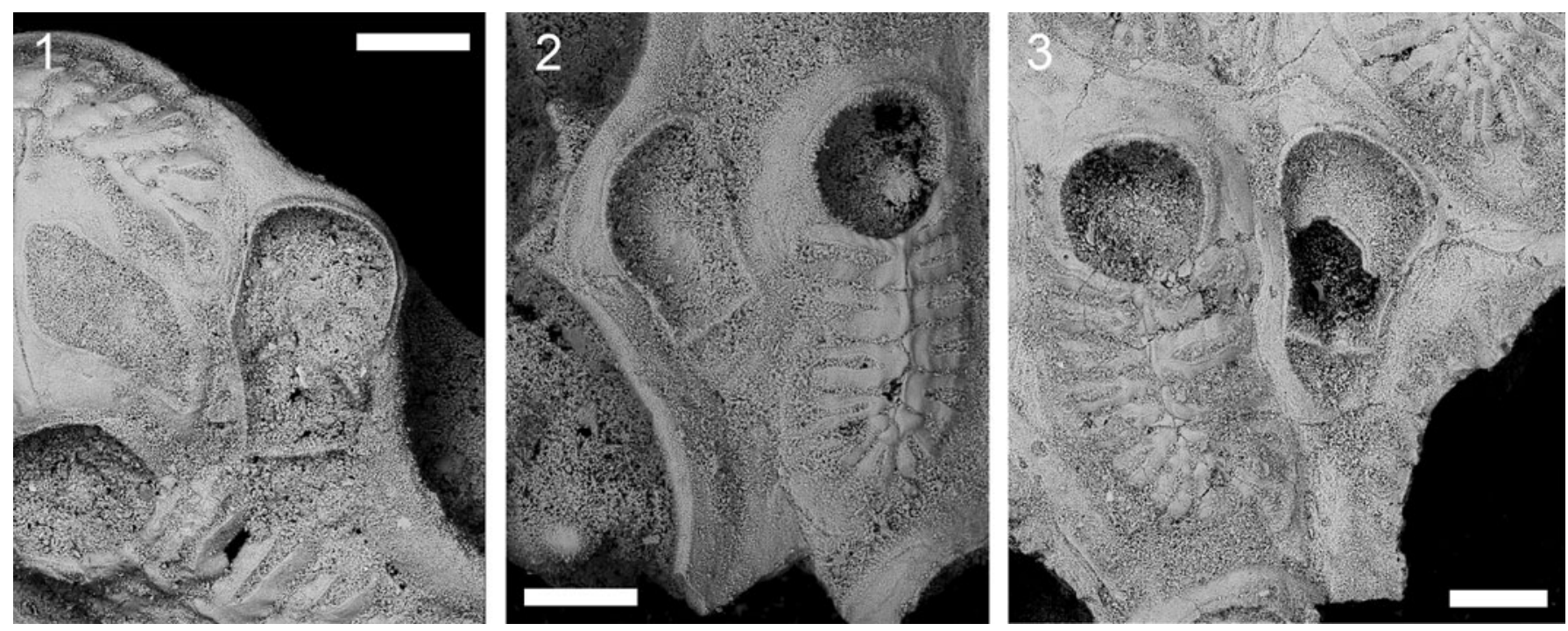

Figure 11. Figularia spectabilis n. sp., Capo Milazzo, sample Cala Sant'Antonino center, 2015, Gelasian, vicarious avicularia. (1) Holotype PMC. B22. 5.4.2015.a; (2, 3) paratypes PMC. B22. 5.4.2015.b, same details as the holotype (note the spatulate rostrum and the thin crossbar); (3) view showing the wide rostral palate. Scale bars: $200 \mu \mathrm{m}$.

the distal kenozooid with frontally visible costate shield of 10 costae, longer than wide, wider and slightly more prominent than the ovicellate zooid (Fig. 9). Very large ooecium consisting of two flat, wing-shaped costae converging along the midline, the fusion marked by a longitudinal suture, distally with two small tubercle-like prominences. Large rhomboidal fenestra exposing finely granular endooecium. Orifice of the ovicellate zooid slightly larger than those of autozooids, rounded rectangular. Closure plates or calcified opercula sometimes occluding orifices (Fig. 10.7).

Etymology.-From the Latin spectabilis, meaning remarkable, exceptional, alluding to the distinctive architecture of the colony and ooecium.

Remarks. - The morphology of the colony, zooids and ooecium distinguish Figularia spectabilis n. sp. from congeners. The flabellate to short, ribbon-like morphology of the colony, with putative heteromorphs placed basally, may suggest the occurrence of basal rhizoids for fixation to the substratum. Alternatively, the connection to an encrusting portion may develop through "sites of articulation" as in Bryobaculum carinatum Rosso, 2002a, occurring in the same sediment.

\section{Discussion}

Five species of cribrilinid bryozoans, three of which are new to science, namely Cribrilaria profunda n. sp., Glabrilaria cf. G. pedunculata, G. transversocarinata n. sp., Figularia figularis, and F. spectabilis n. sp., were found in Pleistocene deepwater sediments from north-eastern Sicily.

Figularia figularis was already recorded from the area by Seguenza (1880) and Neviani (1900), while C. profunda n. sp. was possibly recorded as Lepralia planicosta (see Remarks above), while the remaining three species, including $G$. cf. G. pedunculata, represent new records.
Cribrilinids are generally rare in Plio-Pleistocene associations from deep-water environments in Sicily and Calabria, as well as in their enclaves in shallow waters, such as past submarine cave habitats, from which a single species, Cribrilaria venusta (Canu and Bassler, 1925), and undetermined cribrilinid taxa were previously reported (Di Geronimo et al., 1997, 2005; Rosso, 2005; Rosso et al., 2015). Thus, this study raises the total number of cribrilinids from these paleoenvironments to six species in three genera. Shallower shelf paleoenvironments from the same regions, mostly Pleistocene but as old as Miocene, yielded seven species of cribrilinids: Cribrilaria radiata (Moll, 1803), C. hincksi (Friedl, 1917), C. innominata (Couch, 1844), Puellina gattyae (Landsborough, 1852), Distansescharella seguenzai Cipolla, 1921, Gephyrotes moissettei Di Martino and Rosso, 2015, and "Cribrilina punctata" (Hassall, 1841), the latter species probably being a Collarina (Barrier et al., 1987b; Harmelin et al., 1989; Di Geronimo et al., 1994; Rosso and Sanfilippo, 2005; Di Martino and Rosso, 2015). As for other taxa authored by Seguenza (1880), the loss of the type material makes it difficult to confirm the status of some cribrilinid species, such as Lepralia thiara, L. mitrata, and L. mitrata v. radians, in addition to the previously mentioned L. elegantissima and L. planicosta. Analogously, the real identity of some other species (briefly described and lacking illustrations) in Waters (1878), De Stefani (1884), Hincks (1884), and Neviani (1900, and references therein) is doubtful.

Focusing only on deep-water assemblages, cribrilinids are present with three species in both the Gelasian associations from Capo Milazzo and the Calabrian (MNN19b-19c biozones) of Scoppo. These figures are comparable to those found in present-day deep-water associations from the Mediterranean and Atlantic (Bahama Bank), in which cribrilinids usually occur with 2-3 species (Rosso et al., 2018). However, the Gelasian of Capo Milazzo includes at least 46 cheilostome species, and the cribrilinid relative percentage is $\sim 6 \%$, which is lower than the $10-18 \%$ found in present-day assemblages (Rosso and Sciuto, 2019). No comparison can be made for 
the Calabrian of Scoppo whose bryozoans are still under investigation.

Discovery of a new species of Figularia, F. spectabilis n. sp., led to the emendation of the genus diagnosis and the re-examination of the 32 species and one variety currently assigned to the genus, based on drawings and photographic material available from the literature. This preliminary survey allows us to confidently reassign two species based on published scanning electron micrographs of the type material. The newly proposed combinations are Vitrimurella capitifera (Canu and Bassler, 1929) n. comb. and Hayamiellina quaylei (Powell, 1967a) n. comb., as also suggested by Kukliński et al. (2015). Thirteen species remain doubtful and their assignment to more suitable genera requires examination of the type material (Table 4).

At present, 18 species, including Figularia spectabilis n. sp., match the diagnosis of the genus. This figure will likely change further after a more detailed revision of some fossil species and species left in open nomenclature (see Berning, 2006 for F. haueri and F. figularis; Di Martino et al., 2017 and Cook et al., 2018 for two different Figularia spp.) as well as cryptic species/species complexes (e.g., F. clithridiata and F. fissa). Based on our literature review, the diversity of Figularia is reduced by about one-half, from 33 (including F. spectabilis n. sp.) to 18 species, with a revision in the stratigraphic range, but only little variation in the geographic distribution of the genus. The genus possibly appeared in the Cenozoic of Europe and Australia, and commonly occurred in sediments in the European-Mediterranean area during the Miocene. Of the 12 species of Figularia living today, 10 species are found in the Pacific and Australasian region. Only two species, F. figularis and $F$. dimorpha, fall outside this area, being recorded in the Atlanto-Mediterranean and southwestern Atlantic regions, respectively.

A twofold future investigation is sought. This includes an examination of the type material of all the species in the genus to confirm their status, prioritizing those that appear to remain problematic (see Table 4; issue partially addressed by López Gappa et al., in press), and an accurate re-examination of all species records to refine both the temporal and spatial distribution of the genus and reconstruct its diversification history, as well as disentangle species complexes.

\section{Acknowledgments}

M.H. Dick (University of Hokkaido, Japan), P.E. Bock (National Museum of Victoria, Melbourne, Australia), and N. Vávra (University of Vienna, Austria) are thanked for their kind help with the bibliography. A. Viola (University of Catania) assisted with scanning electron microscopy. L. Vieira (Universidade Federal de Pernambuco, Brasil), D.P. Gordon (NIWA, Wellington, New Zealand), and B. Berning (Oberösterreichisches Landesmuseum, Linz, Austria) provided constructive comments that greatly improved the originally submitted manuscript. This research was supported by the University of Catania "Piano della Ricerca 2016/2018 (code n. 227221132118)" and "PiaCeRi - Piano Incentivi per la Ricerca di Ateneo 2020-22 linea di intervento 2," while sampling of the studied material was carried out in the frame of previous projects. E. Di Martino received funding from the European Research Council (ERC) under the European Union's Horizon 2020 research and innovation program (grant agreement No 724324 to L.H. Liow). A. Ostrovsky thanks the Russian Science Foundation (grant 18-14-00086) for financial support of the studies on cheilostome brood chambers. This is Catania Paleontological Research Group: contribution n. 465.

\section{References}

Ballesteros, E., 2006, Mediterranean coralligenous assemblages: a synthesis of present knowledge, in Gibson, R.N., Atkinson, R.J.A., and Gordon, J.D.M., eds. Oceanography and Marine Biology: An Annual Review: Boca Raton, CRC Press and Taylor and Francis Group, v. 44, p. 123-195.

Barrier, P., 1984, Evolution tectono-sédimentaire pliocène et pléistocène du Détroit de Messine (Italie). [Ph.D. dissertation]: Marseille, France, Université Aix-Marseille II, 270 p.

Barrier, P., 1986, Evolution paléogéographique du Dètroit de Messine au Pliocène et au Pléistocène: Giornale di Geologia, s. 3, v. 48, p. 7-24.

Barrier, P., 1987, Stratigraphie des dépôts pliocènes et quaternaires du Détroit de Messine: Documents et Travaux Institut Gèologique Albert de Lapparent, Paris, v. 11, p. 59-81.

Barrier, P., Di Geronimo, I., and Montenat, C., 1987a, The Messina Strait (Italy): Pliocene and Pleistocene tectono-sedimentary evolution and present environment: Documents et Travaux de l'Institut Géologique Albert de Lapparent, Paris, v. 11, 272 p.

Barrier, P., Casale, V., Costa, B., Di Geronimo, I., Oliveri, O., and Rosso, A., 1987b, La sezione plio-pleistocenica di Pavigliana (Reggio Calabria): Bollettino della Società Paleontologica Italiana, v. 25, p. 107-144.

Barrier, P., Zibrowius, H., Lozouet, P., Montenat, C., Ott d'Estevou, P., Serrano, F., and Soudet, H.J., 1992, Une faune de fond dur du bathyal supérieur dans le Miocène terminal des Cordillères Bétiques (Carboneras, SE Espagne): Mésogée, v. 51, p. 3-13.

Barrier, P., Di Geronimo, I., La Perna, R., Rosso, A., Sanfilippo, R., and Zibrowius, H., 1996, Taphonomy of deep-sea hard and soft bottoms communities: the Pleistocene of Lazzàro (Southern Italy), in Meléndez, G., Blasco, F., and Pérez, I., eds., Tafomonia y Fossilizaciòn, II Reuniòn, Saragoza: Comunicaciòn de la II Reunión de Tafonomia y Fosilizaciòn, p. $39-46$.

Bassler, R.S., 1936, Nomenclatorial notes on fossil and recent Bryozoa: Journal of the Washington Academy of Sciences, v. 26, p. 156-162.

Bassler, R.S., 1953, Bryozoa, in Moore, R.C., ed., Treatise on Invertebrate Paleontology. Part G: Lawrence, Kansas, Geological Society of America and University of Kansas Press, p. G1-G253.

Berning, B., 2006, The cheilostome bryozoan fauna from the Late Miocene of Niebla (Guadalquivir Basin, SW Spain): environmental and biogeographical implications: Mitteilungen aus dem Geologisch-Paläontologischen Institut der Universität Hamburg, v. 90, p. 7-156.

Berning, B., Tilbrook, K.J., and Rosso, A., 2008, Revision of the north-eastern Atlantic and Mediterranean species of the genera Herentia and Therenia (Bryozoa: Cheilostomata): Journal of Natural History, v. 42, p. 1509-1547.

Bishop, J.D.D., and Househam, B.C., 1987, Puellina (Bryozoa; Cheilostomatida; Cribrilinidae) from British and adjacent waters: Bulletin of the British Museum (Natural History), Zoology, v. 53, p. 1-63.

Bock, P.E., 2020, Bryozoa Home Page, at http://www.bryozoa.net/, accessed 7 March 2020.

Bock, P.E., and Cook, P.L., 2001, Revision of the multiphased genus Corbulipora MacGillivray (Bryozoa: Cribrimorpha): Memoirs of Museum Victoria, v. 58, p. 191-213.

Bock, P.E., and Gordon, D.P., 2020, World List of Bryozoa. Cribrilinidae Hincks, 1879, accessed 24 March 2020, through: World Register of Marine Species at: http://www.marinespecies.org/aphia.php?p=taxdetails\&id=110742 on 2020-03-24

Bornet, E., 1888, Note sur une nouvelle espèce de Laminaire (Laminaria rodriguezii) de la Méditerranée: Bulletin de la Société Botanique de France, v. 35, p. 361-366.

Brown, D.A., 1952, The Tertiary Cheilostomatous Polyzoa of New Zealand: London, Trustees of the British Museum (Natural History), $405 \mathrm{p}$.

Brown, D.A., 1958, Fossil cheilostomatous Polyzoa from south-west Victoria: Memoirs of the Geological Survey of Victoria, v. 10, p. 1-90.

Buge, E., 1956, Les Bryozoaires du Pliocène du Cap Bon: Annales des Mines et de la Géologie, Tunis, v. 17, p. 1-97.

Buge, E., 1957, Les Bryozoaires du Néogène de l'Ouest de la France et leur signification stratigraphique et paléobiologique: Mémoires du Muséum National d'Histoire Naturelle, v. 6, p. 1-436. 
Busk, G., 1852, An account of the Polyzoa, and sertularian zoophytes, collected in the Voyage of the Rattlesnake, on the coasts of Australia and the Louisiade Archipelago, in MacGillivray, J., ed., Narrative of the Voyage of the H.M.S. Rattlesnake 1: London, T. \& W. Boone, p. 343-402.

Busk, G., 1884, Report on the Polyzoa collected by H.M.S. Challenger during the years 1873-1876. Part 1. The Cheilostomata: Report on the Scientific Results of the Voyage of the H.M.S. "Challenger", Zoology, v. 10, p. 1-216.

Canu, F., 1900, Révision des Bryozoaires du Crétacé figurés par d'Orbigny. II, Cheilostomata: Bulletin de la Société géologique de France, 3, v. 28, p. 334-463.

Canu, F., and Bassler, R.S., 1920, North American Early Tertiary Bryozoa: Bulletin of the United States National Museum, v. 106, p. 1-879.

Canu, F., and Bassler, R.S., 1925, Les Bryozoaires du Maroc et de Mauritanie: Mémoires de la Société des Sciences Naturelles du Maroc v. 10, p. 1-79.

Canu, F., and Bassler, R.S., 1928, Fossil and Recent Bryozoa of the Gulf of Mexico region: Proceedings of the United States National Museum, v. 72, p. 1-199.

Canu, F., and Bassler, R.S., 1929, Bryozoa of the Philippine region: Bulletin of the United States National Museum, v. 100, p. 1-685.

Canu, F., and Lecointre, G., 1928, Les Bryozoaires cheilostomes des Faluns de Touraine et d'Anjou: Mémoires de la Société Géologique de France, n.s., v. 4 , p. $51-82$.

Cheetham, A.H., 1971, Functional Morphology and Biofacies Distribution of Cheilostome Bryozoa in the Danian Stage (Paleocene) of Southern Scandinavia. Smithsonian Contributions to Palaeobiology: Washington, DC, Smithsonian Institution Press, $87 \mathrm{p}$.

Chimenz Gusso, C., Nicoletti, L., and Bondanese, C., 2014, Briozoi: Biologia Marina Mediterranea, v. 20, p. 1-336.

Cipolla, F., 1921, I briozoi pliocenici di Altavilla presso Palermo: Giornale della Società di Scienze Naturali ed Economiche, Palermo, v. 32, p. 1-132.

Cook, P.L., Bock, P.E., Hayward, P.J., and Gordon, D.P., 2018, Class Gymnolaemata, order Cheilostomata, in Cook, P.L., Bock, P.E., Gordon, D.P., and Weaver, H., eds., Australian Bryozoa, Volume 2: Taxonomy of Australian Families, p. 61-280.

Couch, R.Q., 1844, A Cornish Fauna: being a Compendium of the Natural History of the Country, Intended to Form a Companion to the Collection in the Royal Institution of Cornwall. Part 3. The Zoophytes and Calcareous Corallines: Truro, Royal Institution of Cornwall, 164 p.

De Stefani, C., 1884, Escursione scientifica nella Calabria (1878-79): Jeio, Montalto e Capo Vaticano: Roma, Salviucci, 292 p.

Di Geronimo, I., Giacobbe, S., Rosso, A., and Sanfilippo, R., 1990, Popolamenti e tanatocenosi del Banco Apollo (Ustica, Mar Tirreno meridionale): Bollettino del Museo Regionale di Scienze Naturali di Torino, v. spec. p. 697-729.

Di Geronimo, I., Costa, B., La Perna, R., Randazzo, G., Rosso, A., and Sanfilippo, R., 1994, The Pleistocene "Case Catarinicchia" section (Belice, SW Siciliy), in Matteucci, R., Carboni, M.G., and Pignatti, J.S., eds., Studies on Ecology and Paleoecology of Benthic communities: Bollettino della Società Paleontologica Italiana, v. spec. 2, p. 93-115.

Di Geronimo, I., D’Atri, A., La Perna, R., Rosso, A., Sanfilippo, R., and Violanti, D., 1997, The Pleistocene bathyal section of Archi (Southern Italy): Bollettino della Società Paleontologica Italiana, v. 36, p. 189-212.

Di Geronimo, I., Messina, C., Rosso, A., Sanfilippo, R., Sciuto, F., and Vertino A., 2005, Enhanced biodiversity in the deep: early Pleistocene coral communities from southern Italy, in Freiwald, A., and Roberts, J.M., eds., Deepwater Coral Ecosystems: Berlin, Springer, p. 61-86.

Di Martino, E., and Rosso, A., 2015, Revision of the genus Gephyrotes Norman, 1903 (Cheilostomata, Cribrilinidae) with the description of two new taxa: Zootaxa, v. 3941, p. 261-283.

Di Martino, E., and Taylor, P.D., 2018, Early Pleistocene and Holocene bryozoans from Indonesia: Zootaxa, v. 4419, p. 1-70.

Di Martino, E., Taylor, P.D., and Portell, R.W., 2017, Bryozoans from the lower Miocene Chipola Formation, Calhoun County, Florida, USA: Bulletin of the Florida Museum of Natural History, v. 53, p. 97-200.

D’Onghia, G., Capezzuto, F., Cardone, F., Carlucci, R., Carluccio, A., Chimienti, G., Corriero, G., Longo, C., Maiorano, P., Mastrototaro, F., Panetta, P., Rosso, A., Sanfilippo, R., Sion, L., and Tursi, A., 2015, Macro- and megafauna recorded in the submarine Bari Canyon (southern Adriatic, Mediterranean Sea) using different tools: Mediterranean Marine Science, v. 16 , p. $180-196$.

Duvergier, J., 1924, Deuxième note sur les Bryozoaires du Néogène de l'Aquitaine: Actes de la Société linnéenne Bordeaux, v. 75, p. 145-190.

Ehrenberg, C.G., 1831, Animalia Evertebrata exclusis insectis, in Hemprich, P.C., and Ehrenberg, C.G., Symbolae Physicae, seu Icons et Descriptiones Corporum Naturalium novorum aut minus cognitorum, quae ex itineribus per Libyam Aegyptum, Nubiam, Dongalam, Syriam, Arabiam et Habessiniam. Pars Zoologica, v. 4: Berlin, Berolini, unpaginated.

Esper, E.J.C., 1794, Fortsetzungen der Pflanzenthiere in Abbildungen nach der Natur mit Farben erleuchtet nebst Beschreibungen: Nürnberg, Raspe, v. 1 part 1-2, p. 1-64.
Figuerola, B., Gordon, D.P., and Cristobo, J., 2018, New deep Cheilostomata (Bryozoa) species from the Southwestern Atlantic: shedding light in the dark: Zootaxa, v. 4375 (2.3), p. 211-249.

Fois, E., 1990, Stratigraphy and palaeoceanography of the Capo Milazzo area (NE Sicily, Italy): clues to the evolution of the southern margin of the Tyrrhenian basin during the Neogene: Palaeogeography, Palaeoclimatology, Palaeoecology, v. 78, p. 87-108.

Friedl, P.H., 1917, Bryozoen der Adria: Zoologischer Anzeiger, v. 49, p. 225-240. Gaetani, M., and Saccà, R., 1984, Brachiopodi batiali nel Pliocene e Pleistocene di Sicilia e Calabria: Rivista Italiana di Paleontologia e Stratigrafia, v. 90, p. $407-458$.

Gautier, Y.V., 1956, Résultats scientifiques des campagnes de la Calypso. 2. Études sur l'îlot du Gran Congloué (Archipel de Riou, près Marseille). 5. Bryozoaires: Annales de l'Institut Océanographique, v. 32, p. 189-225.

Gibbard, P.L., Head, M.J., Walker, M.J.C., and the Subcommission on Quaternary Stratigraphy, 2010, Formal ratification of the Quaternary System/Period and the Pleistocene Series/Epoch with a base at $2.58 \mathrm{Ma}$ : Journal of Quaternary Science, v. 25, p. 96-102.

Gordon, D.P., 1984, The marine fauna of New Zealand: Bryozoa: Gymnolaemata from the Kermadec Ridge: New Zealand Oceanographic Institute Memoir, v. 91, p. 1-198.

Gordon, D.P., 1989, The marine fauna of New Zealand: Bryozoa: Gymnolaemata (Cheilostomida Ascophorina) from the western South Island continental shelf and slope: New Zealand Oceanographic Institute Memoir, v. 97, p. $1-158$.

Gordon, D.P., Bock, P.E., Souto-Derungs, J., and Reverter-Gil, O., 2019, A bryozoan tale of two continents: faunistic data for the Recent Bryozoa of Greater Australia (Sahul) and Zealandia, with European comparisons, in Schmidt, R., Reid, C.M., Gordon, D.P., Walker-Smith, G., and Percival, I.P., eds., Bryozoan Studies 2016. Proceedings of the $17^{\text {th }}$ International Bryozoology Association Conference: Memoirs of the Australasian Association of Palaeontologists, v. 52, p. 13-22.

Grischenko, A.V., Gordon, D.P., Ayumu, N., Makoto, K., Naotomo, K., and Mawatari, S.F., 2004, New cheilostome bryozoans from the middle Miocene of Hokkaido, Japan, and the first fossil occurrences of Kubaninella and Hayamiellina gen. nov.: Paleontological Research, v. 8, p. 167-179.

Harmelin, J.-G., 1969, Bryozoaires des grottes sous-marines obscures de la région Marseillaise: faunistique et écologie: Téthys, v. 1, p. 793-806.

Harmelin, J.-G., 1970, Les Cribrilaria (Bryozoaires Chilostomes) de Méditerranée; systématique et écologie: Cahiers de Biologie Marine, v. 11, p. 77-98.

Harmelin, J.-G., 1978, Sur quelques cribrimorphes (Bryozoa, Cheilostomata) d'Atlantique orientale: Tethys, v. 8, p. 173-192.

Harmelin. J.-G., 1979, Aperçu de la faune bryozoologique bathyale du détroit Siculo-Tunisien: Rapport de la Commission Internationale pour l'Exploration Scientifique de la Mer Méditerranée, v. 25/26, p. 171-172.

Harmelin, J.-G., 1984, Bryozoaires des peuplements sciaphiles de Méditerranée: révision de Cribrilina setosa Waters et description de deux nouvelles espèces de Cribrilaria (Bryozoa, Cheilostomata): Zoologica Scripta, v. 13, p. $81-88$.

Harmelin, J.-G., 1988, Espèces affines microsympatriques chez Puellina (Bryozoa, Cheilostomata) et description d'espèces nouvelles: Zoologica Scripta, v. 17 , p. $25-38$.

Harmelin, J.-G., 2001, Puellina saldanhai n. sp., a new cribrimorph cheilostome (Bryozoa: Gymnolaemata) from dark cave environment of southern Portugal: Boletim do Museu Municipal do Funchal (Historia Natural), v. 6 (Supplement), p. 37-49.

Harmelin, J.-G., 2003, Biodiversité des habitats cryptiques marins du parc national de Port-Cros (Méditerranée, France). Assemblages de bryozoaires d'une grotte sous-marine et des faces inférieures de pierres: Scientific Reports Port-Cros National Park, France, v. 19, p. 101-115.

Harmelin, J.-G., 2006, The Puellina flabellifera species complex: a remarkable example of worldwide species radiation in cribrimorph bryozoans: Courier Forschungsinstitut Senckenberg, v. 257, p. 73-92.

Harmelin, J.-G., and Aristegui, J., 1988, New Cribrilinidae (Bryozoa, Cheilostomata) from the upper bathyal of the Atlanto-Mediterranean region: Journal of Natural History, v. 22, p. 507-535.

Harmelin, J.-G., and d'Hondt, J.-L., 1992, Bryozoaires des parages de Gibraltar (campagne océanographique BALGIM, 1984) 1-Chéilostomes: Bulletin du Muséum National d'Histoire Naturelle, Paris, 4, v. 14A, p. 37-67.

Harmelin, J.-G., and d'Hondt, J.-L., 1993, Transfers of bryozoan species between the Atlantic Ocean and the Mediterranean Sea via the Strait of Gibraltair: Oceanologica Acta, v. 16, p. 63-72.

Harmelin, J.-G., Boronat, J., Moissette, P., and Rosso, A., 1989 , Distansescharella seguenzai Cipolla, 1921 (Bryozoa, Cheilostomata), nouvelles données morphologiques et écologiques tirées de spécimens fossiles (Miocène, Pliocène) et recents de Méditerranée: Geobios, v. 22, p. 485-501.

Harmer, S.F., 1926, The Polyzoa of the Siboga Expedition, 2. Cheilostomata Anasca: Siboga Expedition Reports, v. 28b, p. 183-501. 
Harmer, S.F., 1957, The Polyzoa of the Siboga Expedition, Part 4. Cheilostomata Ascophora II: Siboga Expedition Reports, v. 28d, p. 641-1147.

Hassall, A.H., 1841, Supplement to a catalogue of Irish zoophytes: Annals and Magazine of Natural History, ser. 1, v. 7, p. 363-373.

Hayward, P.J., and Cook, P.L., 1983, The South African Museum's Meiring Naude Cruises, part 13, Bryozoa II: Annals of the South African Museum, v. 91 , p. $1-161$

Hayward, P.J., and McKinney, F.K., 2002, Northern Adriatic Bryozoa from the vicinity of Rovinj, Croatia: Bulletin of the American Museum of Natural History, v. 270, p. 1-139.

Hayward, P.J., and Ryland, J.S., 1998, Cheilostomatous Bryozoa. Part 1. Aeteoidea-Cribrilinoidea: Synopses of the British Fauna, New Series, v. 10, 366 p.

Hincks, T., 1879, On the classification of the British Polyzoa: Annals and Magazine of Natural History, ser. 5, v. 3, p. 153-164.

Hincks, T., 1880, Contributions towards a general history of the marine Polyzoa. Part I. Madeiran Polyzoa: Annals and Magazine of Natural History, ser. 6, v. 5 , p. $69-80$.

Hincks, T., 1881, Contributions towards a general history of the marine Polyzoa. Parts IV-VIII: Annals and Magazine of Natural History, ser. 5, v. 7, p. 147 161 ; ser. 5, v. 8, p. 1-14, 122-136.

Hincks, T., 1884, Note on Professor G. Seguenza's list of Tertiary Polyzoa from Reggio (Calabria): Annals and Magazine of Natural History, ser. 5, v. 13, p. 265-267.

Jablonski, D., Lidgard, S., and Taylor, P.D., 1997, Comparative ecology of bryozoan radiations: origin of novelties in cyclostomes and cheilostomes: Palaios, v. 12, p. 505-523.

Johnston, G., 1847, A History of British Zoophytes: London, Van Voorst, 499 p.

Jullien, J., 1886, Les Costulidées, nouvelle famille de Bryozoaires: Bulletin de la Société Zoologique de France, v. 11, p. 601-620.

Kataoka, J., 1961, Bryozoan fauna from the "Ryukyu Limestone" of Kikai-jima, Kagoshima Prefecture, Japan: Science Reports of the Tohoku University, Geology, v. 32, p. 213-272.

Kukliński, P., and Barnes, D.K.A., 2009, A new genus and three new species of Antarctic cheilostome Bryozoa: Polar Biology, v. 32, p. 1251-1259.

Kukliński, P., Grischenko, A.V., and Jewett, S.C., 2015, Two new species of cheilostome bryozoan Cheilopora from the Aleutian Islands: Zootaxa, v. 3963 , p. 434-442.

Lagaaij, R., 1963, New additions to the bryozoan fauna of the Gulf of Mexico: Publications of the Institute of Marine Science, University of Texas, v. 9, p. 181-236.

Landsborough, D., 1852, A Popular History of British Zoophytes, or Corallines: London, Reeve and Co., $404 \mathrm{p}$.

Langer, M.B., 1989, Haftorgan, Internodien und Sklerite von Keratoisis melitensis (Goldfuss, 1826) (Octocorallia) in den pliozänen Foraminiferenmergeln («Trubi») von Milazzo (Sizilien): Paläontologische Zeitschrift, v. 63, p. 15-24.

Li, Z.P., 1990, Bryozoaires de Montbrison-Fontbonau (Drôme) et comparison avec les autres faunes Miocènes du Bassin Rhodanien méridional: Nouvelles Archives du Museum d'Histoire Naturelle Lyon, v. 27, p. 1-126.

Linnaeus, C., 1758, Systema naturae, per regna tria naturae, secundum Classes, Ordines, Genera, Species, cum characteribus, differentiis, synonymis, locis. v. 1: Holmiae, Laurentii Salvii, 824 p.

López-Gappa, J., Pérez, L.M., Almeida, A.C.S., Iturra, D., Gordon, D.P., and Vieira, L.M., In press, Three new cribrimorph bryozoans (order Cheilostomata) from the early Miocene of Argentina, with a discussion on spinocystal shield morphologies: Journal of Paleontology.

MacGillivray, P.H., 1895, A monograph of the Tertiary Polyzoa of Victoria: Transactions of the Royal Society of Victoria, v. 4, p. 1-166.

Manzoni, A., 1875, I briozoi del Pliocene antico di Castrocaro: Bologna, Tipi Gamberini e Parmegiani, $64 \mathrm{p}$.

Maplestone, C.M., 1901, Further descriptions of the Tertiary Polyzoa of Victoria. 6: Proceedings of the Royal Society of Victoria (new series), v. 13, p. 204-213.

Mastrototaro, F., D’Onghia, G., Corriero, G., Matarrese, A., Maiorano, P., Panetta, P., Gherardi, M., Longo, C., Rosso, A., Sciuto, F., Sanfilippo, R., Gravili, C., Boero, F., Taviani, M., and Tursi, A., 2010, Biodiversity of the white coral bank off Cape Santa Maria di Leuca (Mediterranean Sea): an update: Deep Sea Research II, v. 57, p. 412-430.

Milne Edwards, H., 1836, Histoire Naturelle des Animaux sans Vertèbres, v. 2: Paris, J.B. Baillière, 684 p.

Moissette, P., Delrieu, B., and Tsagaris, S., 1993, Bryozoaires du bassin Néogène d'Héraklion (Crète centrale, Grèce). Le Miocène supérieur: premiers résultats: Neues Jahrbuch für Geologie und Paläontologie Abhandlungen, v. 190 , p. $75-123$.

Moll, J.P.C., von, 1803, Eschara, ex Zoophytorum, seu, Phytozoorum Ordine Pulcherrimum ac Notatu Dignissimum Genus, Novis Speciebus Auctum, Methodice Descriptum et Iconibus ad Naturam Delineatis Illustratum: Vindobonae, Camesiniana, $70 \mathrm{p}$.

Neviani, A., 1900, Briozoi neogenici delle Calabrie: Paleontographia Italica, v. 6 , p 115-266.
NMNH 1, National Museum of Natural History, USNM MO 648027 Figularia contraria Lagaaij, 1963 at http://n2t.net/ark:/65665/32aa1e36d-6e1a-4f5aaa66-33f1a5cc20df, accessed 25 March 2020.

NMNH 2, National Museum of Natural History, USNM RB 7494 Figularia ampla Canu \& Bassler, 1928, http://n2t.net/ark:/65665/38429cf89-c125$41 \mathrm{cf}-\mathrm{a} 6 \mathrm{c} 7-\mathrm{e} 2 \mathrm{dfa} 8 \mathrm{~d} 31 \mathrm{fd} 3$, accessed 25 March 2020.

Osburn, R.C., 1950, Bryozoa of the Pacific coast of America, part 1, Cheilostomata-Anasca: Report of the Allan Hancock Pacific Expeditions v. 14 , p. $1-269$.

Ostrovsky, A.N., 2002, Brood chambers in cribrimorphs evolved by fusion of costae: further arguments, in Wyse Jackson, P.N., Buttler, C.J., and Spencer Jones, M.E., eds., Bryozoan Studies 2001: Proceedings of the $12^{\text {th }}$ International Bryozoology Association Conference. Lisse, A.A. Balkema Publishers, p. 247-255.

Ostrovsky, A.N., 2013, Evolution of Sexual Reproduction in Marine Invertebrates: Example of Gymnolaemate Bryozoans: Dordrecht, Springer Science \& Business Media, $356 \mathrm{p}$.

Ostrovsky, A.N., and Schäfer, P., 2003, Ovicell structure in Callopora dumerilii and C. lineata (Bryozoa: Cheilostomatida): Acta Zoologica, v. 84, p. 15-24.

Ostrovsky, A.N., and Taylor, P.D., 2005, Brood chambers constructed from spines in fossil and Recent cheilostome bryozoans: Zoological Journal of the Linnean Society, v. 144, p. 317-361.

Ostrovsky, A.N., Nielsen, C., Vávra, N., and Yagunova, E.B., 2009, Diversity of brood chambers in calloporid bryozoans (Gymnolaemata, Cheilostomata): comparative anatomy and evolutionary trends: Zoomorphology, v. 128 , p. $13-35$.

Powell, N.A., 1967a, Figularia quaylei: new bryozoan from the North-East Pacific: Journal of the Fisheries Research Board of Canada, v. 24, p. 2003-2005.

Powell, N.A., 1967b. Polyzoa (Bryozoa)—Ascophora-from north New Zealand: Discovery Reports, v. 34, p. 199-393.

Prenant, M., and Bobin, G., 1966, Bryozoaires, Deuxieme Partie. Chilostomes Anasca: Paris, Fédération Française des sociétés de sciences naturelles, 647 p.

Reuss, A.E., 1848, Die fossilen Polyparien des Wiener Tertiärbeckens: Haidingers Naturwissenschaftlichen Abhandlungen, v. 2, p. 1-109.

Reuss, A.E., 1874, Die fossilen Bryozoen des österreichisch-ungarischen Miocäns: Denkschriften der Kaiserlichen Akademie der Wissenschaften in Wien. Mathematisch-Naturwissenschaftliche Klasse, v. 33, p. 141-190.

Rio, D., Sprovieri, R., and Di Stefano, E., 1994, The Gelasian Stage: a proposal of a new chronostratigraphic unit of the Pliocene series: Rivista Italiana di Paleontologia e Stratigrafia, v. 100, p. 103-124.

Rosso, A., 2002a, Bryobaculum carinatum sp. n., gen. n., a new Mediterranean Pliocene deep-sea bryozoan, in Wyse Jackson, P.N., Buttler, C.J. and Spencer Jones, M.E., eds., Bryozoan Studies 2001, Proceedings of the $12^{\text {th }}$ International Bryozoology Association Conference: Lisse, A.A. Balkema Publishers, p. 175-182.

Rosso, A., 2002b, Terataulopocella borealis gen. et sp. nov., a deep-water Pliocene lekythoporid (Bryozoa) from the Mediterranean area: Memorie di Scienze Geologiche, v. 54, 65-72.

Rosso, A., 2005, Metrarabdotos (Bryozoa, Cheilostomatida) from PlioPleistocene of southern Italy, with description of new species: Bollettino della Società Paleontologica Italiana, v. 44, p. 11-24.

Rosso, A., and Braga, G., 2013, The genus Sparsiporina d'Orbigny, 1852 (Bryozoa, Cheilostomata): late Eocene to Holocene, in Ernst, A., Schäfer, P., and Scholz, J., eds., Bryozoan Studies 2010. Proceedings of the $15^{\text {th }}$ International Bryozoology Association Conference: Berlin, Heidelberg, Lecture Notes in Earth System Sciences, Springer, v. 143, p. 271-287.

Rosso, A., and Di Martino, E., 2015, Myriapora sciutoi sp. nov., a new fossil Atlanto-Mediterranean bryozoan species and comments on allied taxa: Rivista Italiana di Paleontologia e Stratigrafia, v. 121, p. 369-379.

Rosso, A., and Di Martino, E., 2016, Bryozoan diversity in the Mediterranean Sea: an update: Mediterranean Marine Science, v. 17, p. 567-607.

Rosso, A., and Sanfilippo, R., 2005, Bryozoan and serpuloidean skeletobiont communities from Pleistocene of Sicily: spatial utilisation and competitive interactions, in Fugagnoli, A., and Bassi, D., eds., Giornata di Studi Paleontologici "Prof. C. Loriga Broglio" Ferrara, June 18th, 2004: Annali dell'Università di Ferrara, Sez. Museologia Scientifica e Naturalistica, spec. v., p. 115-130.

Rosso, A., and Sciuto, F., 2019, Fossil record of the bryozoan genus Atlantisina from the Gelasian of Sicily: a new piece to unravel past deep-water bryodiversity of the Mediterranean Sea: Bollettino della Società Paleontologica Italiana, v. 58, p. 141-154.

Rosso, A., Di Martino, E., Sanfilippo, R., and Di Martino, V., 2013a, Bryozoan communities and thanatocoenoses from submarine caves in the Plemmirio Marine Protected Area (SE Sicily), in Ernst, A., Schäfer, P., and Scholz, J., eds., Bryozoan Studies 2010, Proceedings of the $15^{\text {th }}$ International Bryozoology Asssociation Conference: Berlin, Heidelberg, Lecture Notes in Earth System Sciences, Springer, v. 143, p. 251-269.

Rosso, A., Sanfilippo, R., Taddei-Ruggiero, E., and Di Martino, E., 2013b, Serpuloidean, bryozoan and brachiopod faunas from submarine caves in Sicily: Bollettino della Società Paleontologica Italiana, v. 52, p. 167-176. 
Rosso, A., Sanfilippo, R., Ruggieri, R., Maniscalco, R., and Vertino, A., 2015, Exceptional record of submarine cave communities from the Pleistocene of Sicily (Italy): Lethaia, v. 48, p. 133-144.

Rosso, A., Beuck, L., Vertino, A., Sanfilippo, R., and Freiwald, A., 2018, Cribrilinids (Bryozoa, Cheilostomata) associated with deep-water coral habitats in the Great Bahama Bank slope (NW Atlantic), with description of new taxa: Zootaxa, v. 4524 p. 401-439.

Rosso, A., Gerovasileiou, V., Sanfilippo, R., and Guido, A., 2019a, Bryozoans assemblages from two submarine caves in the Aegean Sea (Eastern Mediterranean): Marine Biodiversity, v. 49, p. 707-726.

Rosso, A., Sanfilippo, R., Sciuto, F., Serio, D., Catra, M., Alongi, G., Viola, A., and Leonardi, R., 2019b, Preliminary information on bryozoans associated with selected Cystoseira communities from Sicily (Mediterranean), in Schmidt, R., Reid, C., Gordon, D.P., Walker-Smith, G., Martin, S., and Percival, I., eds., Bryozoan Studies 2016. Proceedings of the $17^{\text {th }}$ International Bryozoology Association Conference: Memoirs of the Australasian Association of Palaeontologists, v. 52, p. 115-129.

Ryland, J.S., and Hayward, P.J., 1992, Bryozoa from Heron Island, Great Barrier Reef: Memoirs of the Queensland Museum, v. 32, p. 223-301.

Sanfilippo, R., Rosso, A., Guido, A., Mastandrea, A., Russo, F., Ryding, R., and Taddei-Ruggiero, E., 2015, Metazooan/microbial biostalactites from modern submarine caves in the Mediterranean Sea: Marine Ecology, v. 36, p. $1277-1293$.

Schneider, C.A., Rasband, W.S., Eliceiri, K.W, 2012, NIH Image to ImageJ: 25 years of image analysis: Nature Methods, v. 9, p. 671-675.

Sciuto, F., 2014a, First report on the palaeopsychrospheric ostracod genus Nemoceratina (Pariceratina) Gründel and Kozur, 1972 (Ostracoda, Bythocytheridae) from the Quaternary of the Mediterranean basin and description of a new species: Paleontologia Electronica, v. 17 (3; 32a), 10 p. palaeo-electronicaorg/content/2014/888-new-quaternary-ostrocod

Sciuto, F., 2014b, Ostracods of the Upper Pliocene-Pleistocene Punta Mazza succession (NE Sicily) with special focus on the Family Trachyleberididae Sylvester-Bradley, 1948, and description of a new species: Carnet de Géologie, v. 14, p. 1-13.

Sciuto, F., 2016, Ostracods associated with deep water corals in the Pleistocene of Scoppo (Messina, Sicily) and description of two new species: Bollettino della Società Paleontologica Italiana, v. 55, p. 205-217.

Seguenza, G., 1876, Ricerche paleontologiche intorno ai Cirripedi Terziarii della provincia di Messina. II. Terza Famiglia Lepadidi Darwin: Atti della Accademia Pontaniana, v. 10, p. 369-481.

Seguenza, G., 1880, Le formazioni terziarie di Reggio (Calabria): Atti della Regia Accademia dei Lincei. Memorie delle Classi Fisiche, Matematiche e Naturali, v. 3, 446 p.

Silén, L., 1941, Cheilostomata Anasca (Bryozoa) collected by Prof. Dr. Sixten Bock's expedition to Japan and the Bonin Islands 1914: Arkiv för Zoologi, v. 33A, p. 1-130.

Smitt, F.A., 1868, Bryozoa marina in regionibus arcticis et borealibus viventia recensuit: Öfversigt af Kongliga Vetenskaps- Akademiens Förhandlingar, v. 24 , p. $443-487$.

Soule, D.F., Soule, J.D., and Chaney, H.W., 1995, Taxonomic Atlas of the benthic fauna of the Santa Maria Basin and western Santa Barbara Channel. The
Bryozoa. Irene McCulloch Foundation Monograph Series, No 2: Los Angeles, Hancock Institute of Marine Studies, University of Southern California, $344 \mathrm{p}$.

Souto, J., Reverter-Gil, O., De Blauwe, H., and Fernández-Pulpeiro, E., 2014, New records of bryozoans from Portugal: Cahiers de Biologie Marine, v. 55, p. $129-150$.

Taylor, P.D., and McKinney, F.K., 2006, Cretaceous Bryozoa from the Campanian and Maastrichtian of the Atlantic and Gulf coastal plains, United States: Scripta Geologica, v. 132, p. 1-346.

Tilbrook, K.J., Hayward, P.J., and Gordon, D.P., 2001, Cheilostomatous Bryozoa from Vanuatu: Zoological Journal of the Linnean Society, v. 131, p. 35-109.

Uttley, G.H., and Bullivant, J.S., 1972, Biological results of the Chatham Islands 1954 Expedition. Part 7. Bryozoa Cheilostomata: New Zealand Oceanographic Institute Memoir, v. 57, p. 1-61.

Vertino, A., 2003, Sclerattiniari plio-pleistocenici ed attuali del Mediterraneo. [Ph.D. dissertation]: Messina, Italy, University of Messina, 306 p.

Vertino, A., Titschack, J., Rosso, A., Di Geronimo, I., and Pino, P., 2013, CWC Pleistocene deposits from "La Montagna" (Messina), in Vertino, A., Basso, D., and Rosso, A., eds., Bridging off-shore and on-land research on carbonate mounds: common concepts and techniques. Buildups from Sicily: Triassic to Quaternary examples: COCARDE Workshop and Field Seminar 2013, 23-27 September, Sicily, Italy, p. 4-11.

Violanti, D., 1988, I foraminiferi plio-pleistocenici di Capo Milazzo: Bollettino del Museo Regionale di Scienze Naturali, Torino, v. 6, p. 359-392.

Violanti, D., 2012, Pliocene Mediterranean foraminiferal biostratigraphy: a synthesis and application to the palaeoenvironmental evolution of northwestern Italy, in Elitok, Ö., ed., Stratigrafic Analysis of Layered Deposits: Rijeka, Croatia, InTech, p. 123-160. Available from: http://www.intechopen.com/ books/stratigraphic-analysis-of-layered-deposits/pliocene-mediterraneanforaminiferal-biostratigraphy-a-synthesis-and-application-to-the-paleoenviro

Waters, A.W., 1878, Bryozoa (Polyzoa) from the Pliocene of Bruccoli (Sicily) Transactions of the Manchester Geological Society, v. 14, p. 465-488.

Waters, A.W., 1887, Bryozoa from New South Wales, North Australia, etc. Part II: Annals and Magazine of Natural History, v. 5, p. 181-203.

Waters, A.W., 1923, Mediterranean and other Cribrilinidae, together with their relationships to Cretaceous forms: Annals and Magazine of Natural History, v. 12 , p. $545-573$.

Winston, J.E., 2005, Re-description and revision of Smitt's "Floridan Bryozoa" in the collection of the Museum of Comparative Zoology, Harvard University: Virginia Museum of Natural History Memoir, v. 7, p. 1-147.

Winston, J.E., Vieira, L.M., and Woollacott, R.M., 2014, Scientific Results of the Hassler Expedition. Bryozoa. No. 2. Brazil: Bulletin of the Museum of Comparative Zoology, v. 161, p. 139-239.

Yang, H.J., Seo, J.E., Min, B.S., Grischenko, A.V., and Gordon, D.P., 2018, Cribrilinidae (Bryozoa: Cheilostomata) of Korea: Zootaxa, v. 4377 p. 216-234.

Accepted: 27 September 2020 